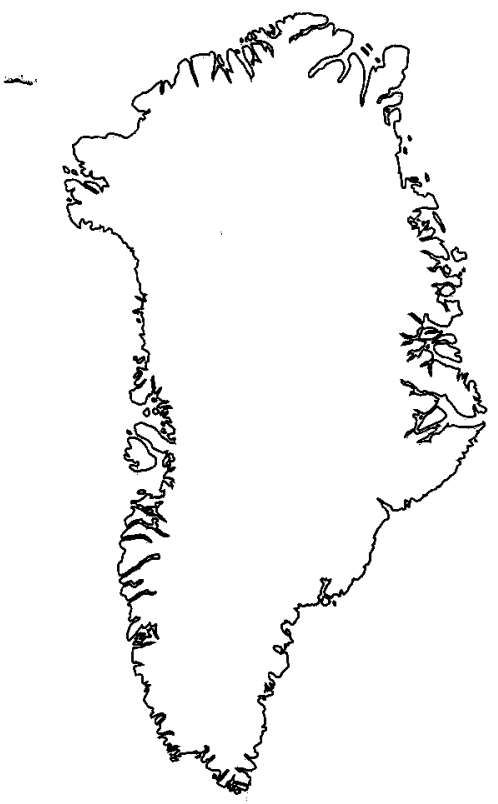

\title{
Filling and plugging of a marine basin by volcanic rocks: the Tunoqqu Member of the Lower Tertiary Vaigat Formation on Nuussuaq, central West Greenland
}

\author{
Asger Ken Pedersen, Lotte Melchior Larsen, Gunver \\ Krarup Pedersen and Keld S. Dueholm
}

The volcanic Tunoqqu Member formed at the end of the second of three volcanic cycles in the Paleocene Vaigat Formation. The Tunoqqu Member consists of brown aphyric and feldspar-phyric basalts and forms a marker horizon within the grey picritic rocks of the Vaigat Formation. Most of the basalts are siliceous and were produced by contamination with crustal rocks of magmas ranging in composition from picrite to evolved basalt.

Some of the basalts were erupted from local volcanic centres of which four have been identified, whereas other basalts form more regional flows. The four identified eruption centres are located along fault lines and zones of uplift and subsidence, indicating tectonic control. Tectonic control is also inferred to be important in terminating the volcanic cycle and causing the development of high-level magma chambers where the magmas stagnated, fractionated, and became contaminated.

The basalts of the Tunoqqu Member form subaerial lava flows in western Nuussuaq. Central Nuussuaq constituted a marine embayment in which the volcanics were deposited as eastward prograding foreset-bedded hyaloclastite breccia fans which indicate water depths of up to $160 \mathrm{~m}$. Eastern Nuussuaq was a gneiss highland with a more than $700 \mathrm{~m}$ high NW-SE-elongated gneiss promontory stretching into the sea. During Tunoqqu Member time the volcanic rocks reached the gneiss promontory and blocked the outlet from the south to the sea in the north. This resulted in increased water levels in the enclosed embayment and transformation of the outlet into a torrential river. This river eroded the concomitantly forming Tunoqqu Member volcanics and the gneiss promontory and deposited the material in up to more than $250 \mathrm{~m}$ thick foreset-bedded boulder conglomerates in the sea where the north coast of Nuussuaq is now situated.

A. K. P., Geological Museum, Øster Voldgade 5-7, DK-1350 Copenhagen K, Denmark. L. M. L., Geological Survey of Denmark and Greenland, Thoravej 8, DK-2400 Copenhagen $N V$, Denmark.

G. K. P., Geological Institute, University of Copenhagen, Øster Voldgade 10, DK-1350 Copenhagen $K$, Denmark.

K. S. D., Institute of Surveying and Photogrammetry, Technical University of Denmark, Landmålervej 7, DK-2800 Lyngby, Denmark.

The early phases of the Tertiary volcanism in the West Greenland Basin are represented by the Vaigat Formation. This formation records a complicated interplay between the concomitantly developing volcanic pile and sedimentary basin through more than 3 million years (Clarke \& Pedersen, 1976; Henderson et al., 1981; Pedersen, 1985a; Pedersen, 1989; Piasecki et al., 1992; Larsen et al., 1992).
On Disko and Nuussuaq (Fig.1) an area of more than $10000 \mathrm{~km}$ is well exposed and only weakly affected by post-volcanic faulting, tilting, and subsidence. In this area the evolution of the volcanic rocks in space and time and their relation to the coeval sediments can be studied in considerable detail. Until recently, such studies have been impeded by the rugged topography and the complex geology. However, the recent development of multi-model 


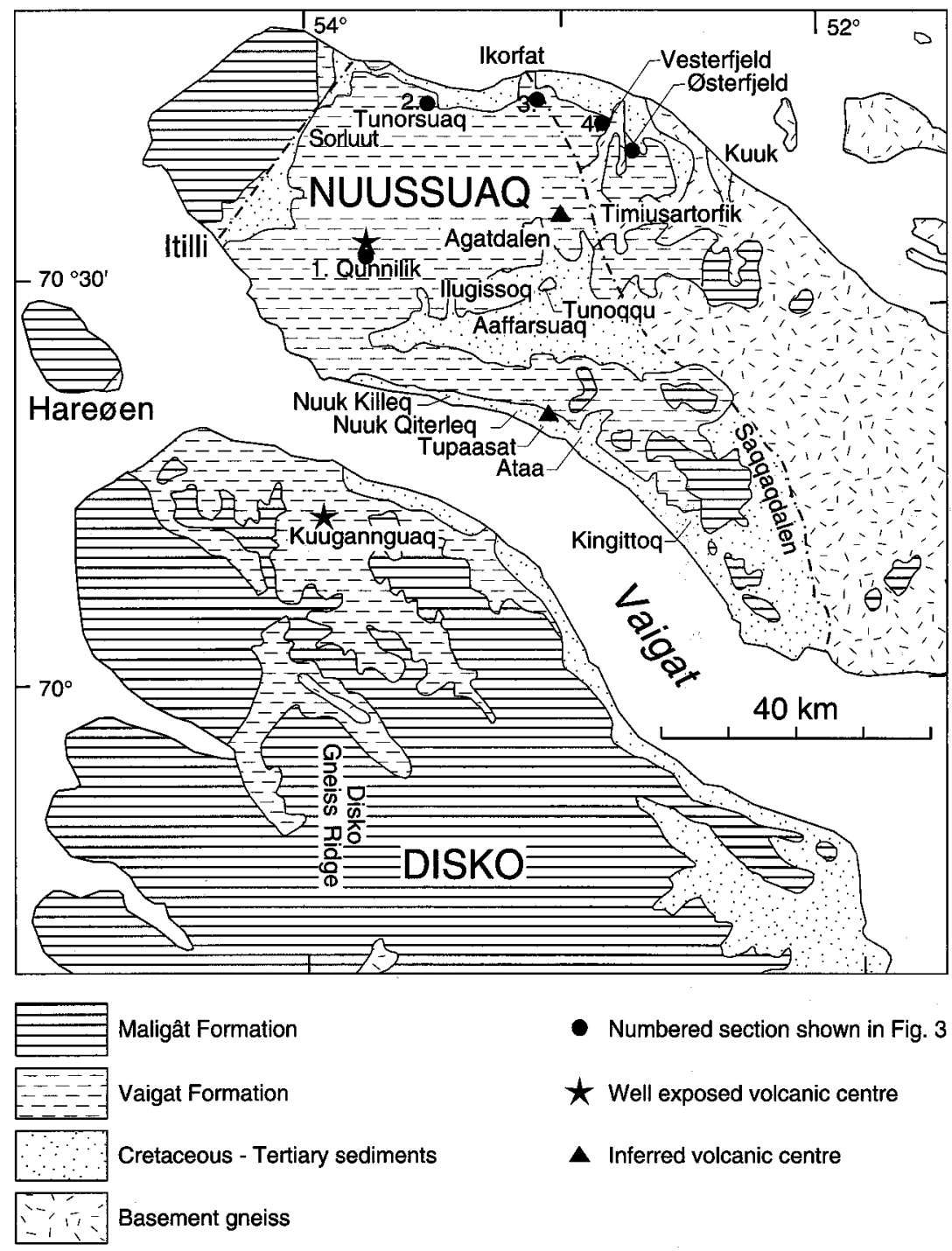

Fig. 1. Geological map of Nuussuaq and central and northern Disko. Kuugannguaq is new spelling of Kûgánguaq.

photogrammetry, based on colour stereo-photography from a helicopter (Dueholm \& Pedersen, 1992; Pedersen \& Dueholm, 1992) has provided the basis for new progress through quantitative studies of inaccessible mountain walls.

Koch (1959) studied the Tertiary non-marine sediments on Nuussuaq. He concluded that parts of the sedimentary succession in the east were contemporaneous with volcanic rocks in the west, and that progradation of volcanic hyaloclastite breccias into a water-covered basin affected the sedimentary facies evolution. Pedersen (1989) likewise suggested that the advancing hyaloclastite fronts caused rapid increases in water depths and changed fluvial plains into deep lakes.

Pedersen et al. (1993) presented a photogrammetrically measured $80 \mathrm{~km}$ long vertical section along the south coast of Nuussuaq. The section documents the eastward younging of the volcanic rocks with time, the eastward progradation of hyaloclastite breccia fans into the watercovered basin, and the variations in water depth with time.

The lithostratigraphy of the Vaigat Formation on Disko (Pedersen, 1985a) and Nuussuaq (Pedersen et al., 1993) is based on a number of lithologically and chemically distinct marker units of contaminated volcanic rocks. These are mostly brown aphyric or feldspar-phyric basalts and andesites which occur as minor horizons within the succession of lithologically uniform grey picritic volcanics. The most widespread of these brown marker horizons is present over large areas of Nuussuaq and is formalised in this paper as the Tunoqqu Member.

Heim (1910) discovered thick conglomerates of basalt 
and gneiss blocks at the base of the volcanic succession at Vesterfjeld in north-eastern Nuussuaq. S. Munck and A. Noe-Nygaard visited the same area in 1939 and discovered that the conglomerates are associated with hyaloclastite breccias (unpublished field notes). The geological map sheet 1:100 000Agatdal shows the conglomerate as a $200 \mathrm{~m}$ thick body which covers $c .1 \mathrm{~km}^{2}$ at the ridge at point $1230 \mathrm{~m}$ named Mellemfjeld by Heim (1910). The conglomerate occurrences were visited in the field in 1992. The conglomerates were found to be part of the Tunoqqu Member and to have a geometry quite different from that shown on the geological map.

This paper combines volcanology, geochemistry, sedimentology, and multi-model photogrammetry in a presentation of a geological analysis of the West Greenland Basin within the narrow time-window represented by the Tunoqqu Member. It demonstrates that this member with its huge conglomerates formed at a critical stage of the development during which a large marine embayment was cut off by the advancing volcanic front and subsequently developed into a fresh-water lake.

\section{Geological setting}

The West Greenland Basin is underlain and bordered to the east by Precambrian gneisses and metasediments of Archaean to Mid-Proterozoic age (Henderson \& Pulvertaft, 1987; Garde \& Steenfelt, in press). The dominant lithologies are quartzo-feldspathic gneisses.

The oldest known sediments in the basin, both onshore and offshore, are of Cretaceous age. On Disko and in southern and central Nuussuaq the Cretaceous sediments include fluvial, deltaic, and marine deposits of the Atane Formation (Pedersen \& Pulvertaft, 1992). The Atane Formation is dated as Albian?-Cenomanian to latest Santonian on the basis of palynomorphs and rare marine invertebrates (Croxton, 1978; Koppelhus \& Pedersen, 1993; Nøhr-Hansen, in press). In central Nuussuaq the Atane Formation is erosively overlain by marine shales of late Cretaceous age (Nøhr-Hansen, 1994).

The basin was affected by considerable tectonic movements in the latest Cretaceous to earliest Tertiary (Rosenkrantz \& Pulvertaft, 1969; Henderson, 1973; Pulvertaft, 1979,1989 ). Block faulting and tilting due to extension led to a general deepening of the basin in western and north-western Nuussuaq, and to uplift and rejuvenation in the eastern, bounding gneiss terrain which became a mountainous area with considerable relief. The tectonism and onset of volcanism in the Tertiary were caused by large scale plate tectonic processes in connection with incipient break-up of the Laurasian continent.

Paleocene pre- to syn-volcanic sediments are exposed in eastern Nuussuaq and northern and eastern Disko. The

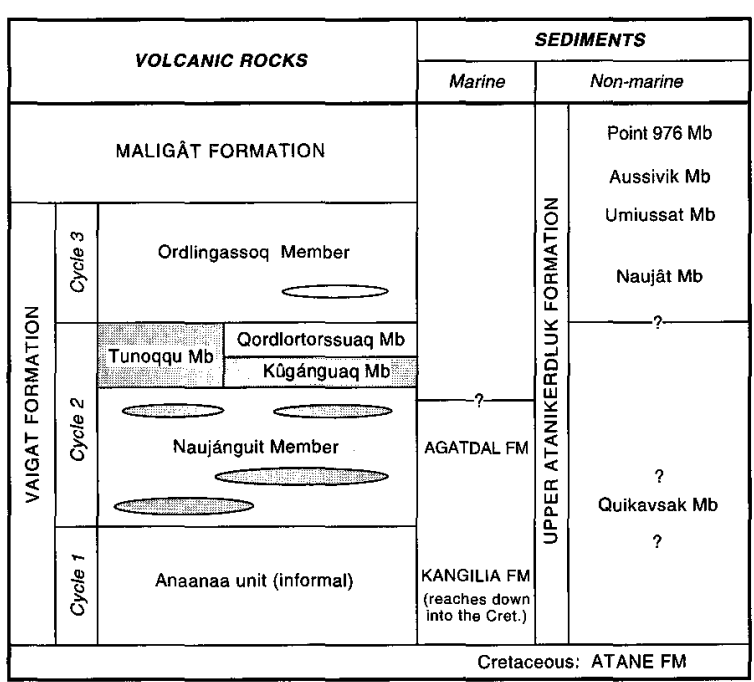

Fig. 2. Summary stratigraphy of the Tertiary volcanic rocks and sediments on Nuussuaq and Disko. The Vaigat Formation comprises three cycles of volcanic activity; various minor members within the formation are shown schematically. Stipple denotes crustally contaminated members.

non-marine sediments on Nuussuaq were described as the Upper Atanikerdluk Formation by Koch (1959), whereas the marine sediments on Nuussuaq are referred to the Kangilia and Agatdal Formations (Rosenkrantz, 1970). The main stratigraphic relationships are illustrated in Fig. 2.

None of the established sediment formations and members are known to be coeval with the volcanic rocks of Tunoqqu Member described here. The marine Kangilia and Agatdal Formations are definitely older (Fig. 2). The dominantly non-marine Quikavsak Member is overlain by the Tunoqqu Member but is rather unconstrained in time (question marks in Fig. 2). The Quikavsak Member is interpreted as a fault-controlled incised valley system filled with fluviatile and estuarine deposits. The valleys were eventually drowned during a phase of rapid rise in relative sea level (Dam \& Sønderholm, in press). The overlying Naujât Member consists of dark grey to black shales which were deposited in relatively deep water. The shales overlie an erosion surface which truncates either the Atane Formation or the Quikavsak Member. The nonmarine (lacustrine) origin of the Naujât Member is inferred from the lack of dinoflagellate cysts and the scarcity or absence of pyrite in the sediment (Piasecki $e t$ al., 1992). These authors suggested that the Naujât Member might be partly coeval with the Tunoqqu Member, but later studies (unpublished data) indicate that the Naujât Member post-dates the Tunoqqu Member and is coeval with the Ordlingassoq Member volcanic rocks (Fig. 2). The shales of the Naujât Member and the younger Aussi- 
Table 1. Lithostratigraphy of the Tunoqqu Member

New member. Forms part of the Lower Tertiary Vaigat Formation (Hald \& Pedersen, 1975). Correlated with Kûgánguaq Member (Pedersen, 1985a).

Name. After the mountain top Tunoqqu on the north side of Aaffarsuaq valley, central Nuussuaq (Fig. 1).

Type section. The south side of Tunoqqu mountain (Fig. 7).

Reference sections. See Figs 1 and 3: Qunnilik (Fig. 3,1), Tunorsuaq (Fig. 3,2), Ikorfat (Fig. 3,3), Vesterfjeld (Fig. 3,4), and Tupaasat (Larsen \& Pedersen, 1988, fig. 2, section c).

Thickness. From less than $50 \mathrm{~m}$ to about $300 \mathrm{~m}$.

Lithology. Brown mostly aphyric and plagioclase-phyric basalts forming subaerial lavas, subaqueous lavas, hyaloclastite breccias, and boulder conglomerates dominated by volcanic clasts.

Boundaries. The Tunoqqu Member rests on grey picritic lava flows and hyaloclastite breccias from the Naujánguit Member, on marine or non-marine Cretaceous sediments, or on Precambrian gneiss. In parts of southern Nuussuaq the lower boundary is not exposed. The Tunoqqu Member is overlain by grey picritic lava flows and hyaloclastite breccias of the Ordlingassoq Member.

Distribution. Tunoqqu Member covers more than $2000 \mathrm{~km}^{2}$ on Nuussuaq (Fig. 5). The extent towards the north and south are delimited by the present coastline, whereas the western extent is delimited by erosion.

vik Member are referred to pollen zones P4 and P5 by Hjortkjær (1991) and are tentatively correlated with marine nannoplankton zones NP6 and NP7 (Piasecki et al., 1992; B. Hjortkjær, personal communication, 1994).

The volcanic rocks on Disko and Nuussuaq are divided into two formations. The older Vaigat Formation consists mainly of primitive, olivine-rich rocks (see below), whereas the younger Maligât Formation consists mainly of feldspar-phyric plateau basalts (Hald \& Pedersen, 1975; Hald, 1977; Larsen \& Pedersen, 1992). Only the Vaigat Formation is considered in the present context.

The Vaigat Formation is subdivided into three main units which are, successively, Anaanaa unit (informal), Naujánguit Member, and Ordlingassoq Member (Pedersen, 1985a; Pedersen et al., 1993, and unpublished data). These units may enclose, or be separated by, a few minor members with distinctive lithology and composition (Fig. 2). Whereas the three main units are dominated by grey, olivine-rich, primitive rocks, most of the minor members consist of brownish-weathering aphyric or feldspar-phyric rocks which are enriched in silica and may contain more or less digested sediment xenoliths. These rocks are interpreted as resulting from reaction between mafic magmas and crustal rocks, and in many cases the reactions occurred in high-level magma chambers within Cretaceous to early Tertiary sediments. Distinctive negative $\mathrm{Ni}$ and $\mathrm{Cu}$ anomalies in some of the sediment-contaminated rocks show that they have been affected by sulphide and iron fractionation (e.g. Pedersen, 1979, 1985b).

\section{Three volcanic cycles of the Vaigat Formation}

The volcanism of the Vaigat Formation started from eruption centres in western Nuussuaq. Subaqueous mounds of pillow breccia and hyaloclastite and sequences of thin subaerial lava flows were deposited. The lavas flowed eastwards and into a deep water-filled basin, presumably of tectonic origin, where they formed huge eastwards-prograding hyaloclastite fans. With time, the active eruption centres also migrated eastwards, and eventually the water-filled basin was filled up. The volcanism occurred in three separate cycles each of which started with olivine-rich primitive magmas and ended with more evolved, often contaminated magmas. These three cycles are represented by the three main units, as follows.

1st cycle: the Anaanaa unit comprises the oldest known Tertiary volcanic rocks in West Greenland. It is only known from a limited area in western Nuussuaq. The rocks comprise picrites, olivine-rich basalts, feldsparphyric basalts, and siliceous contaminated basalts. The unit is considered to be contemporaneous with parts of the marine sedimentary Kangilia Formation to the east and north-east.

2nd cycle: the Naujanguit Member comprises picrites and olivine-rich basalts, whereas the associated minor members mainly consist of siliceous contaminated basalts and andesites with subordinate feldspar-phyric basalts. During the Naujánguit Member cycle the volcanic rocks prograded considerably towards the east on both Disko and Nuussuaq and filled in the marine basin. The Tunoqqu Member, which is the subject of the present paper, 
formed at the end of this volcanic cycle. The 2 nd cycle is considered contemporaneous with the uppermost part of the marine sedimentary Kangilia Formation, with the uppermost part of the marine sedimentary Agatdal Formation, and with parts of the Quikavsaq Member of the Upper Atanikerdluk Formation (Fig. 2).

3rd cycle: the Ordlingassoq Member is the most widespread of the three main units. The rocks comprise almost exclusively picrites and olivine-rich basalts. During the third cycle the volcanic migration eastwards continued, and large parts of the gneiss terrain were onlapped by volcanic rocks. The member is probably contemporaneous with parts of the sedimentary Naujât and Umiussat Members (Fig. 2).

\section{Tunoqqu Member}

The formal lithostratigraphy of the Tunoqqu Member is given in Table 1 and in descriptions and sections presented below.

The basalts of the Tunoqqu Member cover an area of more than $2000 \mathrm{~km}^{2}$ on Nuussuaq. The rocks are contemporaneous with the volcanic rocks of the Kûgánguaq Member on Disko (Pedersen, 1985a, b). Type and reference sections through the Tunoqqu Member are shown in Figs 3 and 7. A crude estimate of the minimum volume of erupted rocks is in the order of $50 \mathrm{~km}^{3}$

The Tunoqqu Member volcanic rocks show a substantial compositional diversity and form a number of compositional groups (Fig. 4, Tables 2 and 3). Rocks from some of these groups have a limited areal distribution and were erupted from local volcanic centres, whereas rocks from other groups occur widely dispersed and without apparent relations to specific volcanic centres. Four local volcanic centres, including the contemporaneous Kûgánguaq centre (new spelling: Kuugannguaq), are shown in Fig. 1.

1. Kûgánguaq Member on Disko was erupted from vents situated in the eastern side of Kuugannguaq valley in northern Disko (Pedersen, 1985b).

2. Around Tupaasat on the south coast of Nuussuaq a distinct series of brown pahoehoe lavas and hyaloclastites occur (Pedersen et al., 1993). No eruption sites have been located. A section is presented in Larsen \& Pedersen (1988, fig. 2 section C).

3. In Qunnilik valley on Nuussuaq a large compound lava composed of numerous individual pahoehoe flows forms a rusty brown marker horizon, and a neck-shaped feeder body is located in the northern side valley. The flow attains a maximum thickness of c. $30 \mathrm{~m}$ and a volume of at least $0.6 \mathrm{~km}^{3}$. The eruption site is situated near to a later $\mathrm{N}-\mathrm{S}$ trending hinge zone which was probably also active in Tunoqqu Member time.

4. In the inner part of Agatdalen Tunoqqu Member

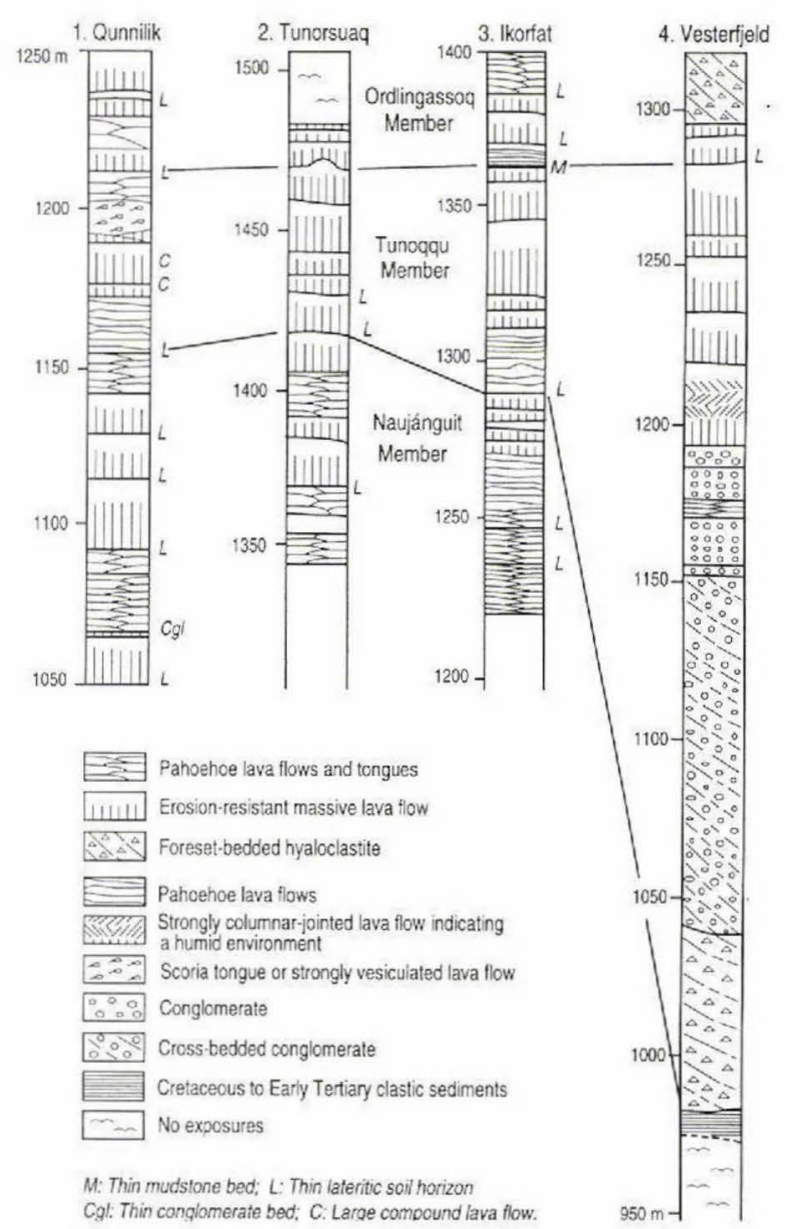

Fig. 3. Reference sections for the Tunoqqu Member. Location of the sections is shown in Fig. 1. Detailed locations are as follows. Section 1: western side of unnamed side valley to Qunnilik valley, $70^{\circ} 33^{\prime} 46^{\prime} \mathrm{N}, 53^{\circ} 45^{\prime} 10^{\prime} \mathrm{W}$. Section 2 : northern side of Tunorsuaq valley, $70^{\circ} 42^{\prime} 54^{\circ} \mathrm{N}, 53^{\circ} 27^{\prime} 04^{\prime \prime} \mathrm{W}$. Section 3: eastern side of glacier south of Ikorfat, $70^{\circ}, 44^{\circ} 04^{\prime \prime} \mathrm{N}, 53^{\circ} 03^{\circ} 45^{\prime \prime} \mathrm{W}$. Section 4: eastern side of Vesterfjeld, $70^{\circ} 42^{\prime} 57^{\prime} \mathrm{N}, 52^{\circ} 51^{\prime} 41^{\prime \prime} \mathrm{W}$.

contains some strongly silica-enriched lavas which are probably derived from a local but as yet unidentified volcanic centre in this region.

In addition to these local centres, a number of Tunoqqu Member lava flows are widely distributed between the Aaffarsuaq valley and the north coast of Nuussuaq. Some individual lava flows have been followed for more than $25 \mathrm{~km}$ between Tunorsuaq and Vesterfjeld in northern Nuussuaq.

\section{Chemical variation}

The chemical variation within the Tunoqqu Member is illustrated in Fig. 4. Representative analyses of rocks 
Table 2. Chemical analyses of rocks from the volcanic centres and dispersed lavas from the Tunoqqu Member, Nuussuaq

\begin{tabular}{|c|c|c|c|c|c|c|c|c|c|c|}
\hline GGU & 400208 & 400238 & 400239 & 400307 & 400204 & 340711 & 362020 & 332703 & 400129 & 362039 \\
\hline $\mathrm{SiO}_{2}$ & 46.15 & 51.44 & 54.14 & 52.65 & 51.59 & 49.89 & 51.39 & 49.25 & 50.31 & 47.60 \\
\hline $\mathrm{TiO}_{2}$ & 1.22 & 1.55 & 1.82 & 1.38 & 1.34 & 0.97 & 1.30 & 1.44 & 1.57 & 1.88 \\
\hline $\mathrm{Al}_{2} \mathrm{O}_{3}$ & 11.45 & 15.03 & 14.73 & 14.83 & 14.80 & 12.33 & 14.57 & 14.82 & 15.23 & 13.46 \\
\hline $\mathrm{Fe}_{2} \mathrm{O}_{3}$ & 3.68 & 5.24 & 1.68 & 2.41 & 3.65 & 1.06 & 0.85 & 2.77 & 2.47 & 4.80 \\
\hline $\mathrm{FeO}$ & 7.56 & 5.12 & 7.82 & 6.84 & 6.13 & 8.66 & 8.52 & 8.19 & 7.64 & 5.74 \\
\hline $\mathrm{MnO}$ & 0.17 & 0.18 & 0.16 & 0.15 & 0.16 & 0.16 & 0.19 & 0.17 & 0.16 & 0.15 \\
\hline $\mathrm{MgO}$ & 17.39 & 5.73 & 5.13 & 8.16 & 8.23 & 14.90 & 11.19 & 7.69 & 8.18 & 9.37 \\
\hline $\mathrm{CaO}$ & 9.4 & 10.17 & 8.93 & 9.77 & 10.39 & 8.02 & 8.58 & 12.80 & 10.76 & 10.69 \\
\hline $\mathrm{Na}_{2} \mathrm{O}$ & 1.45 & 2.65 & 2.61 & 1.92 & 1.79 & 1.38 & 1.59 & 1.96 & 2.02 & 1.94 \\
\hline $\mathrm{K}_{2} \mathrm{O}$ & 0.090 & 0.910 & 0.740 & 0.454 & 0.257 & 0.287 & 0.432 & 0.136 & 0.328 & 0.920 \\
\hline $\mathrm{P}_{2} \mathrm{O}_{5}$ & 0.109 & 0.160 & 0.225 & 0.156 & 0.150 & 0.140 & 0.169 & 0.125 & 0.199 & 0.221 \\
\hline \multirow[t]{2}{*}{ Vol } & 1.19 & 1.31 & 1.36 & 1.13 & 1.54 & 1.82 & 1.51 & 0.90 & 1.04 & 3.18 \\
\hline & 99.86 & 99.48 & 99.34 & 99.85 & 100.03 & 99.62 & 100.29 & 100.26 & 99.92 & 99.94 \\
\hline $\mathrm{Cr}$ & 1350 & 192 & 387 & 645 & 624 & 1186 & 1048 & 484 & 762 & 502 \\
\hline $\mathrm{Ni}$ & 705 & 49 & 19 & 121 & 131 & 81 & 23 & 72 & 56 & 203 \\
\hline $\mathrm{Sc}$ & 34 & 36 & 36 & 33 & 34 & 26 & 32 & 42 & 36 & 31 \\
\hline V & 263 & 269 & 199 & 256 & 258 & 216 & 238 & 345 & 256 & 289 \\
\hline $\mathrm{Cu}$ & 125 & 42 & 21 & 34 & 38 & 18 & 13 & 98 & 44 & 107 \\
\hline $\mathrm{Zn}$ & 87 & 83 & 93 & 85 & 85 & 84 & 87 & 92 & 90 & 88 \\
\hline $\mathrm{Ba}$ & 17 & 809 & 401 & 200 & 142 & 81 & 129 & 65 & 277 & 175 \\
\hline $\mathrm{Sr}$ & 136 & 313 & 241 & 211 & 209 & 133 & 180 & 218 & 247 & 274 \\
\hline $\mathrm{Rb}$ & 0.8 & 17 & 31 & 16 & 10 & 11 & 7.5 & 2.9 & 9.9 & 31 \\
\hline Y & 19 & 27 & 34 & 23 & 22 & 20 & 22 & 23 & 27 & 24 \\
\hline $\mathrm{Zr}$ & 58 & 119 & 187 & 111 & 113 & 93 & 129 & 82 & 113 & 113 \\
\hline $\mathrm{Nb}$ & 2.0 & 17 & 17 & 7.9 & 8.8 & 4.9 & 8.2 & 7.5 & 12 & 20 \\
\hline $\mathrm{Ga}$ & 17 & 19 & 22 & 20 & 20 & 15 & 17 & 19 & 21 & 20 \\
\hline $\mathrm{Pb}$ & $<2$ & 3 & 6 & 5 & $<2$ & 4 & 4 & $<2$ & $<2$ & 4 \\
\hline Th & $<1$ & 2 & 8 & 6 & 4 & 2 & 3 & 2 & 5 & 3 \\
\hline
\end{tabular}

Major elements: GGU's chemical laboratory. XRF except for $\mathrm{Na}_{2} \mathrm{O}$ (AAS) and FeO (titration).

Trace elements: XRF, John Bailey, Geological Institute, University of Copenhagen.

400208: Uncontaminated picrite lava from Naujánguit Member, representing a possible parent magma for the magmas of Tunoqqu Member. West side of side valley to Qunnilik valley, $40 \mathrm{~m}$ below Tunoqqu Mb. $70^{\circ} 33^{\prime} 46^{\prime} \mathrm{N}, 53^{\circ} 45^{\prime} 10^{\prime} \mathrm{W}$, alt. $1114 \mathrm{~m}$.

400238: Aphyric basalt lava from the Agatdal volcanic centre. Mountain ridge in northern part of Agatdalen, $70^{\circ} 35^{\prime} 45^{\prime} \mathrm{N}, 53^{\circ} 07^{\prime} 30^{\prime} \mathrm{W}$, alt. $705 \mathrm{~m}$.

400239: As 400238, alt. $610 \mathrm{~m}$.

400307: Plagioclase-orthopyroxene-olivine-phyric basalt, volcanic neck (feeder) from the Qunnilik volcanic centre. West side of side valley to Qunnilik valley, $70^{\circ} 34^{\prime 2} 24^{\prime \prime} \mathrm{N}, 53^{\circ} 45^{\prime} 10^{\prime \prime} \mathrm{W}$, alt. $1150 \mathrm{~m}$.

400204: Orthopyroxene-olivine-phyric basalt lava flow from the Qunnilik volcanic centre. West side of side valley to Qunnilik valley, $70^{\circ} 33^{\prime} 46^{\prime \prime} \mathrm{N}, 53^{\circ} 45^{\prime} 10^{\prime \prime} \mathrm{W}$, alt. $1185 \mathrm{~m}$.

340711: Olivine-phyric basalt hyaloclastite breccia from the Tupaasat volcanic centre. Tupaasat, south coast of Nuussuaq, $70^{\circ} 21^{\prime} 11^{\prime} \mathrm{N}$, $53^{\circ} 05^{\prime} 12^{\prime \prime} \mathrm{W}$, alt. $750 \mathrm{~m}$.

362020: Aphyric basalt, thin pahoehoe lava flow from the Tupaasat volcanic centre. South coast of Nuussuaq between Tupaasat and Nuuk Qiterleq, $70^{\circ} 21^{\prime} 33^{\prime \prime} \mathrm{N}, 53^{\circ} 10^{\prime} 58^{\prime} \mathrm{W}$, alt. $825 \mathrm{~m}$.

332703: Plagioclase-olivine-phyric basalt, subaqueous lava flow. Tunoqqu type section, central Nuussuaq, $70^{\circ} 30^{\prime} 26^{\prime} \mathrm{N}, 53^{\circ} 04^{\prime} 20^{\circ} \mathrm{W}$, alt. $c .906 \mathrm{~m}$.

400129: Olivine-plagioclase-phyric basalt lava flow. Tunorsuaq valley, NW Nuussuaq, $70^{\circ} 42^{\prime} 54^{\prime} \mathrm{N}, 53^{\circ} 27^{\prime} 04^{\prime} \mathrm{W}$, alt. $1508 \mathrm{~m}$.

362039: Olivine-phyric basalt lava flow with slightly enriched chemistry. South coast of Nuussuaq $7.5 \mathrm{~km}$ west of Nuuk Killeq. $70^{\circ} 23^{\prime} 50^{\prime} \mathrm{N}, 53^{\circ} 38^{\prime} 37^{\prime \prime}$, alt. $1110 \mathrm{~m}$. 
Table 3. Chemical analyses of volcanic rocks from the Tunoqqu Member in the profile at Vesterfjeld, north-eastern Nuussuaq

\begin{tabular}{|c|c|c|c|c|c|c|c|c|c|}
\hline GGU & 400333 & 400332 & 400330 & 400335 & 400338 & 400339 & 400340 & 400341 & 400342 \\
\hline $\mathrm{SiO}_{2}$ & 53.89 & 53.04 & 52.08 & 51.38 & 50.36 & 50.30 & 48.76 & 52.90 & 51.69 \\
\hline $\mathrm{TiO}_{2}$ & 1.64 & 1.73 & 1.39 & 1.38 & 1.59 & 1.59 & 1.36 & 1.37 & 1.53 \\
\hline $\mathrm{Al}_{2} \mathrm{O}_{3}$ & 14.93 & 14.77 & 14.97 & 15.08 & 14.33 & 14.35 & 13.91 & 15.77 & 15.24 \\
\hline $\mathrm{Fe}_{2} \mathrm{O}_{3}$ & 1.28 & 3.02 & 2.15 & 3.74 & 2.51 & 2.78 & 2.69 & 2.26 & 2.25 \\
\hline $\mathrm{FeO}$ & 7.97 & 6.59 & 7.50 & 6.06 & 7.75 & 7.54 & 7.65 & 6.98 & 7.88 \\
\hline $\mathrm{MnO}$ & 0.16 & 0.17 & 0.16 & 0.19 & 0.18 & 0.17 & 0.18 & 0.16 & 0.17 \\
\hline $\mathrm{MgO}$ & 5.99 & 5.51 & 7.57 & 7.30 & 8.60 & 8.52 & 10.84 & 6.50 & 6.70 \\
\hline $\mathrm{CaO}$ & 8.88 & 9.86 & 9.57 & 9.75 & 10.85 & 10.93 & 10.57 & 10.24 & 10.81 \\
\hline $\mathrm{Na}_{2} \mathrm{O}$ & 2.41 & 2.12 & 2.21 & 1.98 & 2.13 & 2.09 & 1.73 & 1.92 & 2.07 \\
\hline $\mathrm{K}_{2} \mathrm{O}$ & 0.602 & 0.429 & 0.308 & 0.279 & 0.295 & 0.339 & 0.333 & 0.390 & 0.645 \\
\hline $\mathrm{P}_{2} \mathrm{O}_{5}$ & 0.200 & 0.214 & 0.155 & 0.150 & 0.161 & 0.164 & 0.155 & 0.144 & 0.161 \\
\hline \multirow[t]{2}{*}{ Vol } & 1.58 & 2.22 & 1.37 & 2.02 & 0.86 & 0.68 & 1.40 & 0.86 & 0.44 \\
\hline & 99.52 & 99.67 & 99.44 & 99.31 & 99.62 & 99.46 & 99.58 & 99.49 & 99.59 \\
\hline $\mathrm{Cr}$ & 459 & 431 & 666 & 736 & 481 & 505 & 1020 & 744 & 765 \\
\hline $\mathrm{Ni}$ & 24 & 20 & 31 & 33 & 177 & 166 & 107 & 15 & 28 \\
\hline $\mathrm{Sc}$ & 37 & 36 & 35 & 33 & 37 & 38 & 35 & 36 & 39 \\
\hline V & 212 & 213 & 248 & 245 & 307 & 312 & 277 & 243 & 273 \\
\hline $\mathrm{Cu}$ & 26 & 27 & 27 & 29 & 87 & 80 & 48 & 18 & 37 \\
\hline $\mathrm{Zn}$ & 91 & 91 & 89 & 96 & 87 & 92 & 90 & 86 & 88 \\
\hline $\mathrm{Ba}$ & 370 & 262 & 239 & 158 & 157 & 177 & 221 & 197 & 172 \\
\hline $\mathrm{Sr}$ & 236 & 281 & 235 & 231 & 226 & 232 & 234 & 232 & 219 \\
\hline $\mathrm{Rb}$ & 30 & 13 & 18 & 11 & 7.3 & 5.0 & 5.5 & 14 & 18 \\
\hline $\mathrm{Y}$ & 30 & 32 & 24 & 24 & 25 & 25 & 22 & 24 & 25 \\
\hline $\mathrm{Zr}$ & 167 & 174 & 124 & 125 & 107 & 105 & 92 & 121 & 115 \\
\hline $\mathrm{Nb}$ & 15 & 16 & 11 & 11 & 9 & 8.7 & 10 & 7.3 & 8.8 \\
\hline $\mathrm{Ga}$ & 20 & 23 & 19 & 21 & 21 & 21 & 19 & 20 & 21 \\
\hline $\mathrm{Pb}$ & 4 & 6 & 7 & 9 & 5 & 4 & $<2$ & $<2$ & 2 \\
\hline Th & 6 & 7 & 5 & 5 & 1 & 2 & 1 & 1 & 2 \\
\hline
\end{tabular}

Major elements: GGU's chemical laboratory. XRF except for $\mathrm{Na}_{2} \mathrm{O}$ (AAS) and $\mathrm{FeO}$ (titration).

Trace elements: XRF, John Bailey, Geological Institute, University of Copenhagen.

400333: Aphyric basalt, clast in conglomerate, alt. $1150 \mathrm{~m}$.

400332: Aphyric basalt, clast in conglomerate, alt. $1150 \mathrm{~m}$.

400330: Aphyric basalt, pillow in hyaloclastite breccia, alt. $1150 \mathrm{~m}$.

400335: Aphyric basalt, $2 \mathrm{~m}$ thick pahoehoe lava flow, alt. $1180 \mathrm{~m}$.

400338: Olivine-microphyric basalt, $25 \mathrm{~m}$ thick lava flow, no. 1 above conglomerates, alt. $1193 \mathrm{~m}$.

400339: Olivine-microphyric basalt, $10 \mathrm{~m}$ thick lava flow, no. 2 above conglomerates, alt. $1220 \mathrm{~m}$.

400340: Olivine-phyric basalt, $15 \mathrm{~m}$ thick lava flow, no. 3 above conglomreates, alt. $1234 \mathrm{~m}$.

400341: Plagioclase-augite-phyric basalt, $5 \mathrm{~m}$ thick lava flow, no. 4 above conglomerates, alt. $1255 \mathrm{~m}$.

400342: Plagioclase-augite-olivine-phyric basalt, min. $25 \mathrm{~m}$ thick lava flow, no. 5 above conglomerates, alt. $1260 \mathrm{~m}$.

The Vesterfjeld profile is shown in Fig. 3 and its location is given there.

typical of the various centres and of the more dispersed flows are given in Table 2, and analyses showing the variation within one profile (Vesterfjeld) are given in Table 3.

The rocks of the Tunoqqu and Kûgánguaq Members span a large range of $\mathrm{MgO}$ contents (5-16\%), but the different compositional groups present cannot be related by ordinary crystal fractionation processes because this would require that they followed evolutional trends as those shown in Fig. 4 for uncontaminated rocks. Instead, crustal contamination is the major controlling factor, as has been shown for the Kûgánguaq Member by Pedersen (1985b).

Many rocks of the Tunoqqu Member are distinctly silica-enriched and clearly contaminated, whereas other rocks, including those from the profile at Tunoqqu, with $49-50 \% \mathrm{SiO}_{2}$ are not clearly contaminated although their 

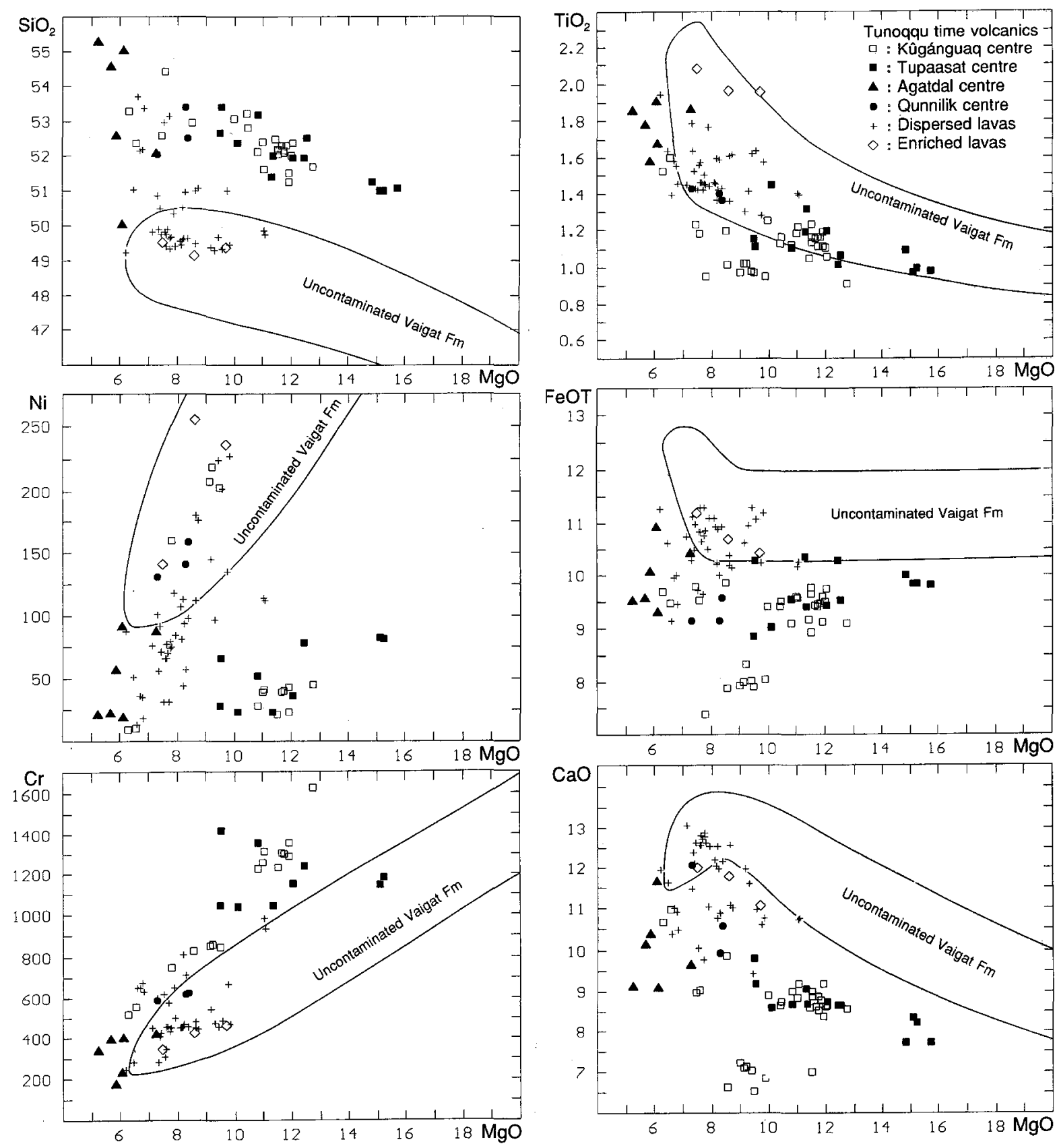

Fig. 4. Diagrams of the variation of $\mathrm{TiO}_{2}$, FeOT (total iron as $\mathrm{FeO}$ ), $\mathrm{CaO}, \mathrm{SiO}_{2}, \mathrm{Ni}$ and $\mathrm{Cr} v$. $\mathrm{MgO}$ for volcanic rocks of the Tunoqqu Member and the coeval Kûgánguaq Member. Rocks from the four identified volcanic centres are indicated. The variation trends for uncontaminated rocks from the Vaigat Formation (mainly unpublished data) are shown for reference.

slight displacement within the 'normal' ranges for the Vaigat Formation towards high $\mathrm{SiO}_{2}$ and low $\mathrm{FeOT}, \mathrm{CaO}$ and $\mathrm{Ni}$ show that they may be just slightly contaminated. The group of lavas with $49-50 \% \mathrm{SiO}_{2}$ and $6-10 \% \mathrm{MgO}$ represents essentially normal, evolved, feldspar-phyric and aphyric basalts.

A group of lavas with $50-51 \% \mathrm{SiO}_{2}$ have low FeOT and low $\mathrm{CaO}$ outside the normal range and are probably contaminated evolved rocks.

All four local eruption centres have produced highly silicic, strongly contaminated rocks. The Kûgánguaq and Tupaasat centres both produced silicic high-Mg basalts with 9-13\% $\mathrm{MgO}$ (Tupaasat centre up to $16 \%$ $\mathrm{MgO}$ ) and distinctly low $\mathrm{FeOT}, \mathrm{CaO}$ and $\mathrm{TiO}_{2}$. The 
uncontaminated parents for these rocks must have been picrites with at least $18 \% \mathrm{MgO}$, estimated from the high $\mathrm{Cr}$ contents in the resultant rocks. The low Ni contents in most of these rocks are indicative of sulphide fractionation (Pedersen, 1985b). The Kûgánguaq centre in addition produced magnesian andesites with $8-10 \% \mathrm{MgO}$ and $56-59 \% \mathrm{SiO}_{2}$ (not shown in the $\mathrm{SiO}_{2}$ diagram), and silicic feldspar-phyric basalts.

The Agatdalen centre produced low- $\mathrm{Mg}$ basalts and andesites with $50-55 \% \mathrm{SiO}_{2}$. They have relatively high $\mathrm{TiO}_{2}$ contents, low $\mathrm{Cr}$, and very low $\mathrm{Ni}$ contents in continuation of the uncontaminated evolution trend for $\mathrm{Ni}$. This indicates that the parent magma for this centre was evolved basalt similar to or more evolved than the almost uncontaminated dispersed lavas from the Tunoqqu Member.

The Qunnilik centre produced silicic basalts with around $8 \% \mathrm{MgO}$, fairly similar to the silicic feldspar-phyric basalts from the Kûgánguaq centre. According to the $\mathrm{Cr}$ contents the parent magma for this centre would have had at least $12 \% \mathrm{MgO}$. There are no signs in the Ni contents of sulphide fractionation.

Some dispersed lavas show the same silica enrichment as the lavas of the centres. Such lavas occur in several profiles but correlation between them is equivocal.

A lava with c. $11 \% \mathrm{MgO}$ (Table 3, 400340) occurs in two neighbouring profiles and is sufficiently characteristic to be unequivocally correlatable. It is slightly contaminated from a parent with at least $14 \% \mathrm{MgO}(\mathrm{Cr}$ diagram), and it is sulphide fractionated (Ni diagram).

A few lavas enriched in $\mathrm{TiO}_{2}$ and $\mathrm{P}_{2} \mathrm{O}_{5}$ (Table 2, 362039) occur at the top of the Tunoqqu Member in two neighbouring profiles and are probably from the same, late eruption centre.

In conclusion, the Tunoqqu Member is characterised by a range of dominantly silicic basalts produced contemporaneously in a number of independent volcanic reservoirs by contamination of magmas ranging in composition from picrite to evolved basalt.

\section{Geographical distribution of the Tunoqqu Member}

The areal extent of the Tunoqqu Member is shown in Fig. 5. In the following description of the terrains and the volcanic products, the area in which the Tunoqqu Member has been identified is subdivided into five: the western subaerial lava plain; the eastern gneiss highland; the marine embayment in between; the western volcanic shore zone; and the conglomerate-dominated areas at the north coast of Nuussuaq.

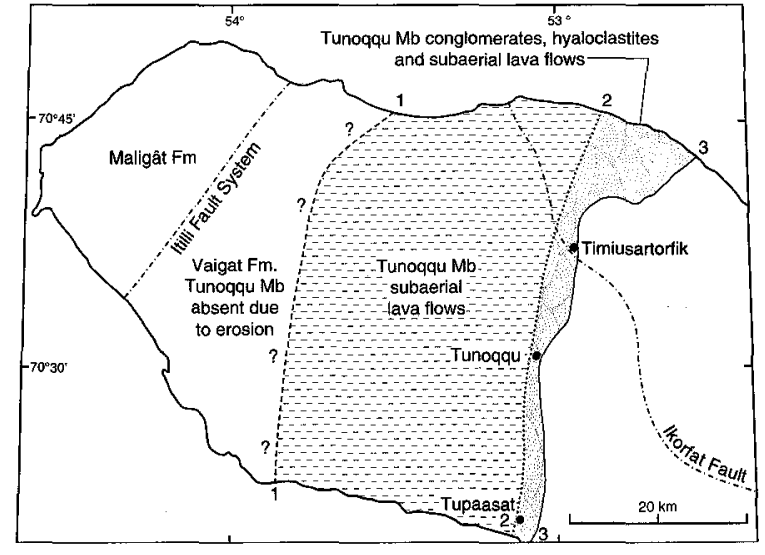

Fig. 5. Geographical distribution of the Tunoqqu Member. Line 1-1: Approximate western limit of exposures of the Tunoqqu Member, controlled by the present topography.

Line 2-2: Earliest shoreline, where the oldest Tunoqqu Member lavas entered the marine embayment.

Line 3-3: The eastern limit of progradation of Tunoqqu Member volcanic rocks.

The three named localities are described later in the text.

\section{Western subaerial lava plain}

Just prior to the formation of the Tunoqqu Member, central and western Nuussuaq and northern Disko were covered by a lava plain of picritic pahoehoe lavas. This lava plain extended east to a shore zone shown on Fig. 5. In central Nuussuaq an older, partly buried crater cone of graphite andesite tuffs at Ilugissoq (Fig. 1) rose about $30 \mathrm{~m}$ above the lava plain. Other irregularities were associated with zones of local synvolcanic tectonic movements. Two such zones have been documented through detailed photogrammetric work: a zone of uplift north of Nuuk Killeq associated with extension (Fig. 1; Pedersen \& Dueholm, 1992, fig. 10; Pedersen et al., 1993), and a zone of gentle subsidence on the western fringe of the Ikorfat fault system (Fig. 1).

\section{Eastern gneiss highland}

Fig. 6 shows a simplified contour map of parts of the gneiss highland on Nuussuaq east of the Ikorfat fault system and north of the Aaffarsuaq valley at the end of Tunoqqu Member time. The gneiss highland shows local topographic relief of several hundred metres. Many details of the relief have been preserved under the cover of later lavas which has been stripped off only in comparatively recent time.

The essential feature of the gneiss highland is a NWtrending ridge extending from eastern Nuussuaq to just east of Agatdalen. It had the form of a promontory 


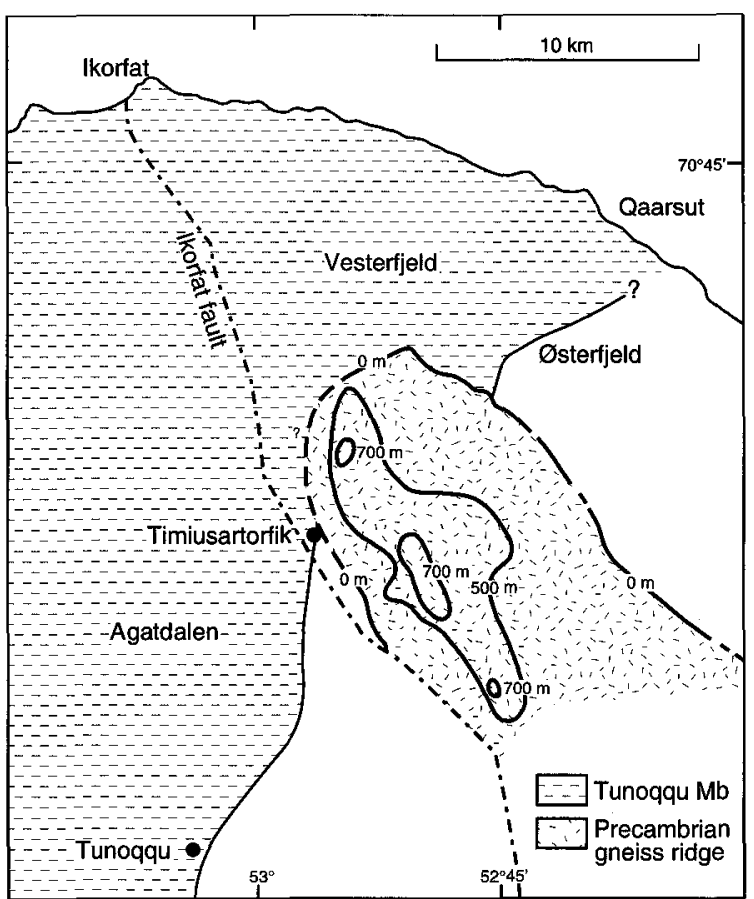

Fig. 6. Detailed palaeogeographical map of parts of the eastern gneiss highland and its surroundings at the end of Tunoqqu Member time. The contours on the gneiss ridge were compiled from the contours on the 1:100 000 map sheet Agatdal, with the top of the Tunoqqu Member taken as reference (zero) level, and assuming no later tilting in the area. The eastern boundary of the Tunoqqu Member is drawn at its maximum eastern extent. The localities Tunoqqu and Timiusartorfik are described later in the text and shown in Figs 7-9.

extending into the sea and rising to more than $500 \mathrm{~m}$, locally more than $700 \mathrm{~m}$ above the surroundings, with no documented cross-cutting channels. The NW end of the promontory is now buried beneath volcanic rocks and may have been affected by post Vaigat Formation downthrow to the west along the Ikorfat fault system. The shape of the gneiss ridge is probably tectonically controlled: its NW trend is sub-parallel to the Ikorfat fault system, and also to a prominent direction of dyke intrusion on both Disko and Nuussuaq (e.g. Pedersen, 1977), indicating tension in a SW-NE direction.

At the time just prior to the formation of the Tunoqqu Member the progressively eastwards advancing subaerial lava plain turned the marine embayment in south central Nuussuaq into an enclosed water body connected to the sea in the north only through a comparatively narrow strait between the volcanic front and the gneiss promontory.

\section{The marine embayment}

The geological section along the south coast of Nuussuaq (Pedersen et al., 1993) shows that the hyaloclastite breccias of the Naujánguit Member decrease in thickness eastwards. The height of the foresets in the hyaloclastite fans from the Tunoqqu Member shows water depths of c. $160 \mathrm{~m}$ at that time.The coeval eastern clastic shoreline is tentatively positioned in the vicinity of Kingittoq (Fig. 13).This was done by backstripping to an extensive plateau lava flow from the Maligât Formation (Pedersen et al., 1993, unit mM; and Pedersen \& Dueholm, 1992, fig. 14).

Further north, in the inner part of Saqqaqdalen, Pulvertaft (1989) noted a marked relief on the boundary between the Atane Formation and the overlying Naujât Member, whereas no traces of Quikavsak Member were found. This may indicate that erosion of the Atane Formation continued into Tunoqqu Member time. The clastic shoreline thus lay to the west of inner Saqqaqdalen.

The palaeogeographic reconstruction in Fig. 13 shows the inferred extension of the marine embayment and proposes the existence of a low-energy shoreline to the east. Very little clastic sediment accumulated during the time of hyaloclastite breccia progradation.

\section{Western volcanic shore zone}

The volcanic rocks of the Tunoqqu Member entered the marine embayment from the west, along a shoreline running roughly $\mathrm{N}-\mathrm{S}$ from southern to central Nuussuaq. Here the line turned slightly to the NE towards the present north coast of Nuussuaq (Fig. 5). The shore is characterised below by means of detailed descriptions of three localities shown on Fig. 5.

Tupaasat. A section through the shore zone where Tunoqqu Member lavas entered the sea is exposed at Tupaasat and also shown by Larsen \& Pedersen (1988, fig. 2, loc. C) and Pedersen et al. (1993, at about $32 \mathrm{~km}$, the easternmost contaminated basalts grouped with the Asuk Member). The sediments of the sea floor are not exposed but are supposed to be clastic sediments from the Quikavsaq Member, possibly covered by mudstone. A series of foreset-bedded Tunoqqu Member hyaloclastite breccias indicate infilling from the south-west and a minimum water depth of $160 \mathrm{~m}$. These are covered by c. $50 \mathrm{~m}$ of thin subaerial pahoehoe flows of silicic magnesian basalt (Table 2) which successively go into hyaloclastite facies over a horizontal distance of $800 \mathrm{~m}$. At the eastern end of the exposure the last lava has entered the water. The Tunoqqu Member volcanic rocks are covered by thin lenses of mudstone that were deformed when the overlying 


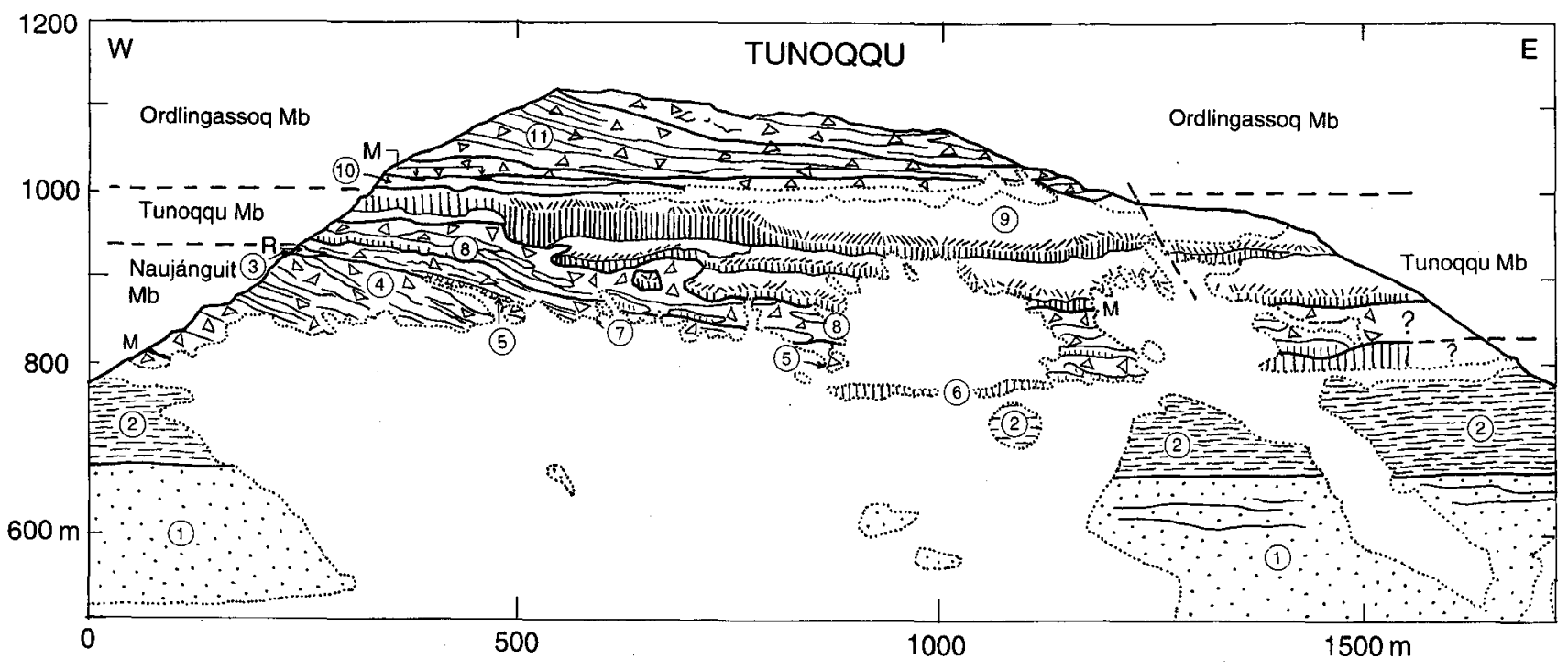

Vaigat Formation, (Paleocene)

Picritic subaerial lava flow
Strongly columnar-jointed basalt lava
indicating a humid environment

Upper Cretaceous marine clastic sediments

Shale, locally with intraformational (2) $=0$ conglomerates at base

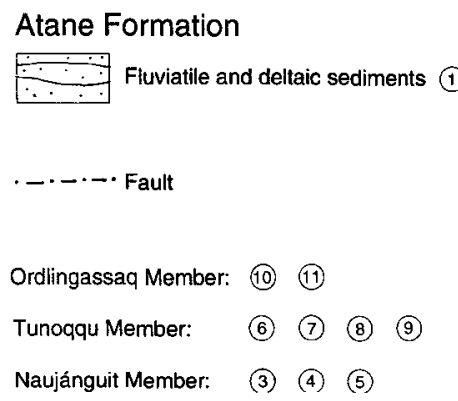

Fig. 7. The south side of Tunoqqu mountain. The section was compiled from colour diapositives by multi-model photogrammetry. The projection plane is vertical, west-east orientated, looking north. At this locality the Tunoqqu Member lavas flowed from the west into the marine basin. A shore zone in the older Naujánguit Member rocks is defined by a rocky coast of eroded lavas (R) and local conglomerates (5) derived by erosion of lavas and hyaloclastites. The Tunoqqu Member rocks are a lava invasive into sediments (6), and hyaloclastite breccias and subaqueous lava tongues ( 7 and 8 ) overlain by strongly columnar-jointed partly subaqueous lavas (9). One lava flow has bulldozed into the underlying hyaloclastites and thickened to form an $80 \mathrm{~m}$ deep lava pond that just surfaced above the water level.

hyaloclastites of the Ordlingassoq Member were deposited. One dinoflagellate cyst was found in a sample of these mudstones (Piasecki et al., 1992, loc. 9).

Tunoqqu. The south side of the small mountain Tunoqqu in central Nuussuaq displays an excellent east-west section approximately perpendicular to the Tunoqqu Member shore zone (Figs 7 and 8). The Atane Formation is here overlain by grey ammonite-bearing marine shales which are generally poorly exposed. These shales may perhaps belong to the Kangilia Formation but formally they have not been referred to any formation. The preTunoqqu Member shore consists of foreset-bedded picrite hyaloclastites covered by a few metres of subaerial picrite lava flows from the Naujánguit Member. Both hyaloclastites and particularly the lavas have been eroded by wave action under conditions of relatively rising water level. The lavas are sculpted as a rocky, boulder-strewn coast, and conglomerate and gravel of rounded picrite lava cobbles and re-worked hyaloclastite are deposited 

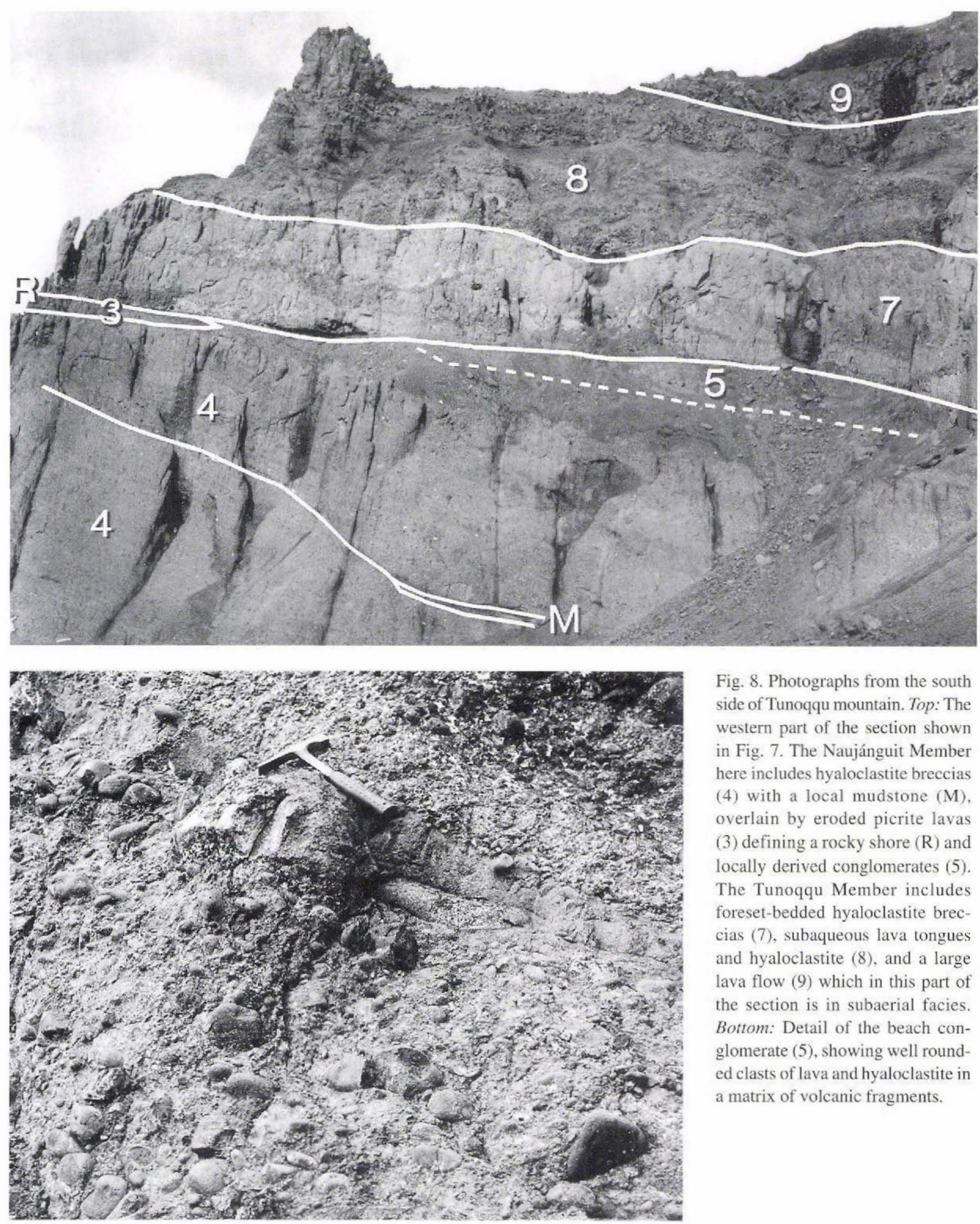

Fig. 8. Photographs from the south side of Tunoqqu mountain. Top: The western part of the section shown in Fig. 7. The Naujánguit Member here includes hyaloclastite breccias (4) with a local mudstone (M), overlain by eroded picrite lavas (3) defining a rocky shore ( $R$ ) and locally derived conglomerates (5). The Tunoqqu Member includes foreset-bedded hyaloclastite breccias (7), subaqueous lava tongues and hyaloclastite (8), and a large lava flow (9) which in this part of the section is in subaerial facies. Bottom: Detail of the beach conglomerate (5), showing well rounded clasts of lava and hyaloclastite in a matrix of volcanic fragments.

along a sloping, slightly eroded hyaloclastite shelf up to $120 \mathrm{~m}$ deep. The lowest unit of the Tunoqqu Member is a foreset-bedded hyaloclastite breccia with pillow lava tongues. It is covered by a series of small subaqueous lava tongues embedded in hyaloclastite and with local patches of mudstone on the top. The upper part of the 

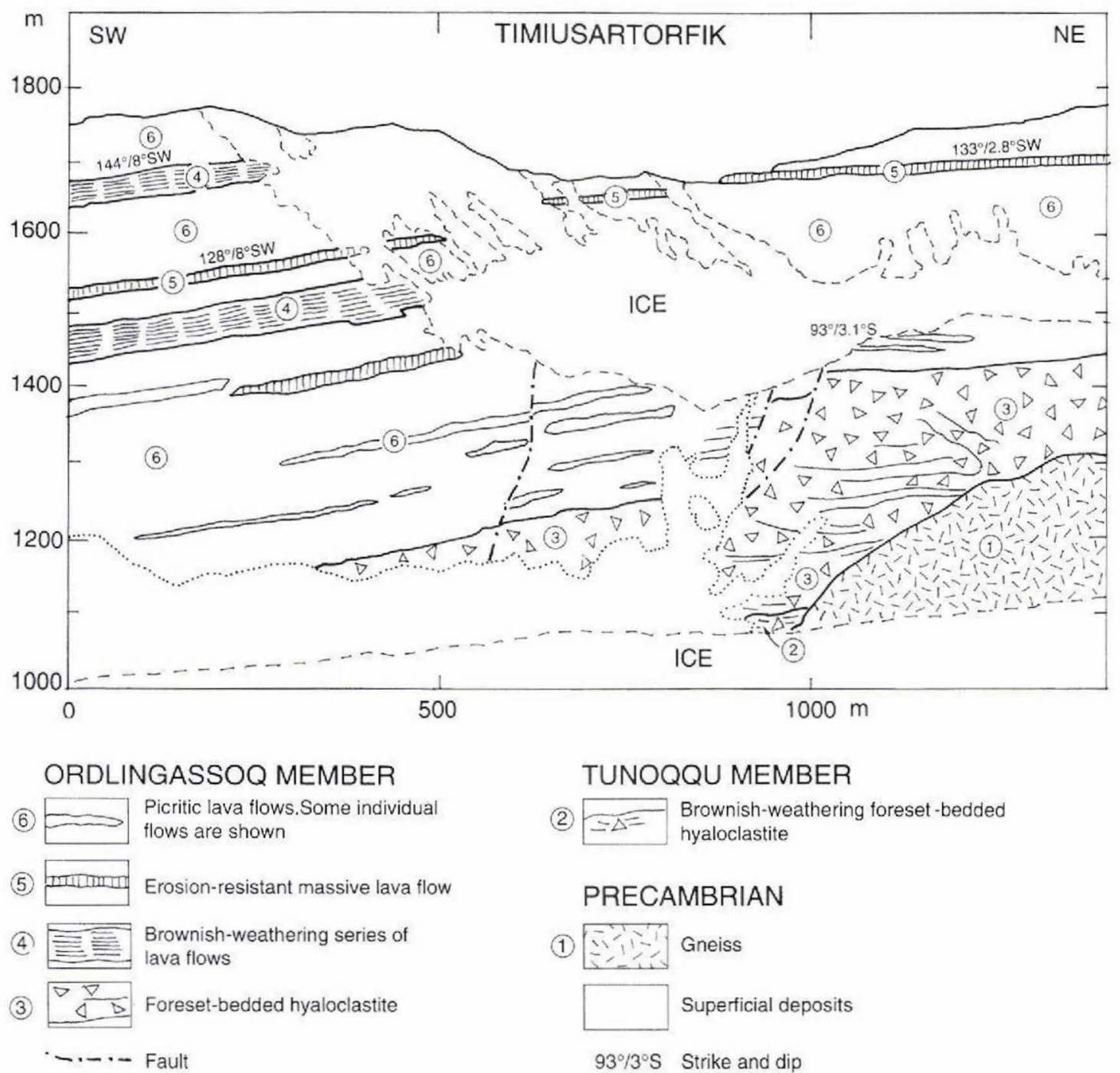

\section{TUNOQQU MEMBER}

(2) $=\Delta=$ Brownish-weathering foreset -bedded hyaloclastite

\section{PRECAMBRIAN}

(1)

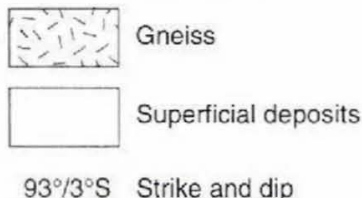

Fig. 9. Timiusartorfik. The section was compiled from colour diapositives by multi-model photogrammetry. The projection plane is vertical, SW-NE orientated, looking NW. The Ikorfat fault system runs through the section and is approximately perpendicular to it. The lowermost volcanic unit (2) is brown hyaloclastite or conglomerate from the Tunoqqu Member, onlapping Precambrian gneiss (1). The Tunoqqu Member is covered by several hundred metres of hyaloclastite breccia from the Ordlingassoq Member (3). The lavas south-west of the fault zone dip about $8^{\circ} \mathrm{SW}$ and define a shallow syncline along the margin of the Ikorfat fault.

Tunoqqu Member consists of distinctly columnar-jointed basalt lavas. The uppermost of these lavas shows a very well developed transition from subaerial to subaqueous facies. In the western part of the section it is a $25 \mathrm{~m}$ thick aa lava with the top showing high-temperature subaerial oxidation. Where the lava reached the shore zone it bulldozed into the underlying brecciated units which caused a local thickening of the flow to $60 \mathrm{~m}$. Farther into the basin it formed a $80 \mathrm{~m}$ thick ponded lava that built up right to the surface of the basin. The top zone of the subaerial part of the lava is reworked into a minor basalt conglomerate with rounded oxidised clasts and finingupwards structure. A relative rise in the water level of $35 \mathrm{~m}$ during the interval pre- to end-Tunoqqu Member time is indicated. The Tunoqqu Member is covered by a c. $10 \mathrm{~m}$ thick picrite lava flow from the Ordlingassoq Member. This flow is in places covered by up to $40 \mathrm{~cm}$ of mudstone deposited in local depressions, and this is again covered by more than $100 \mathrm{~m}$ of Ordlingassoq Member picrite hyaloclastites.

Timiusartorfik. About $14 \mathrm{~km} \mathrm{NNE}$ of Tunoqqu $25 \mathrm{~m}$ 

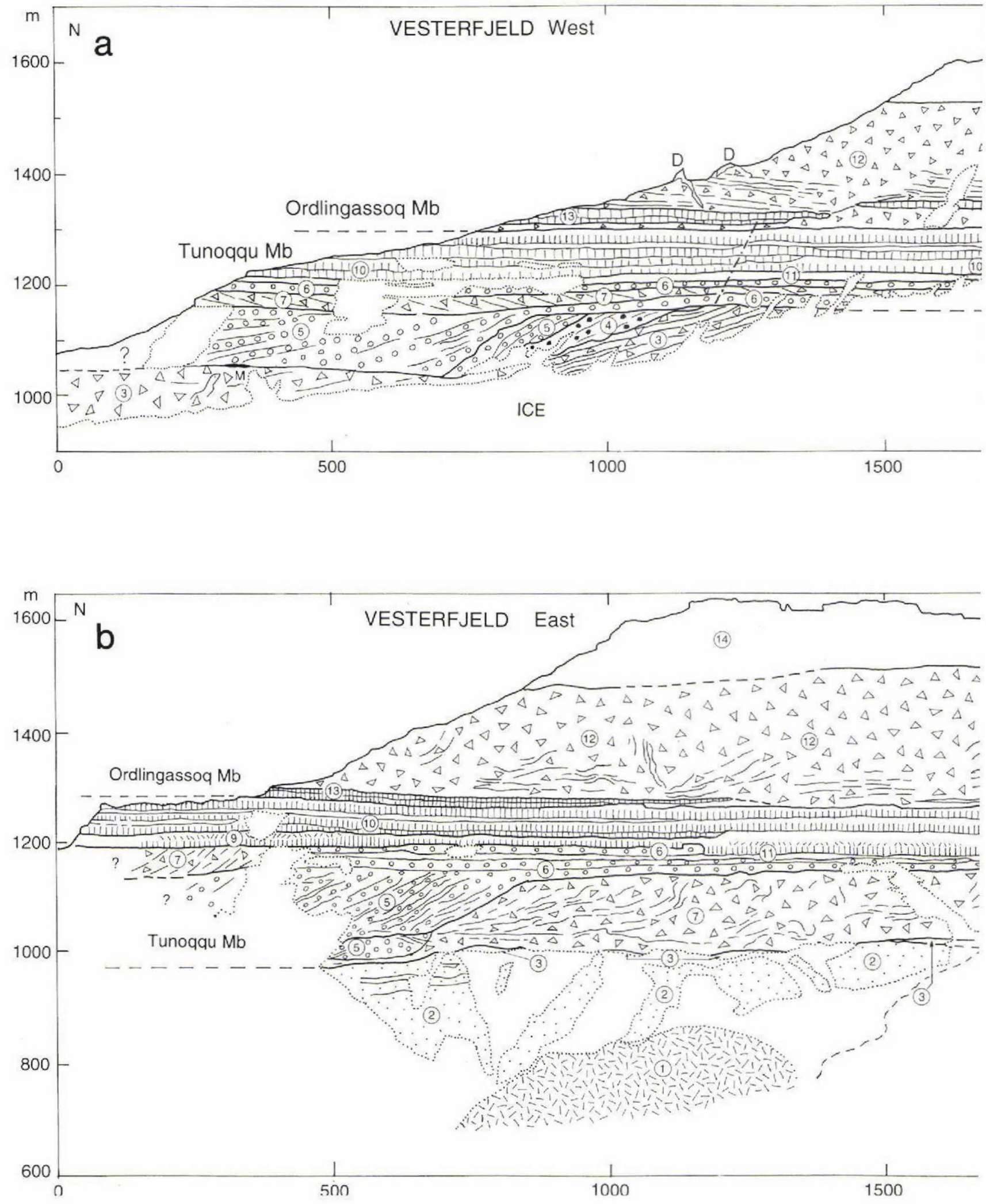

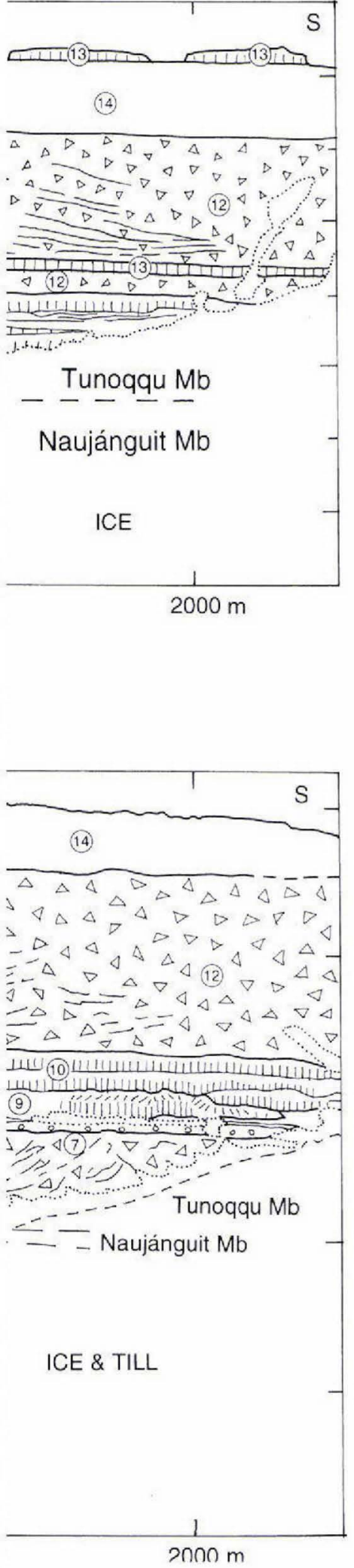

Continued next page

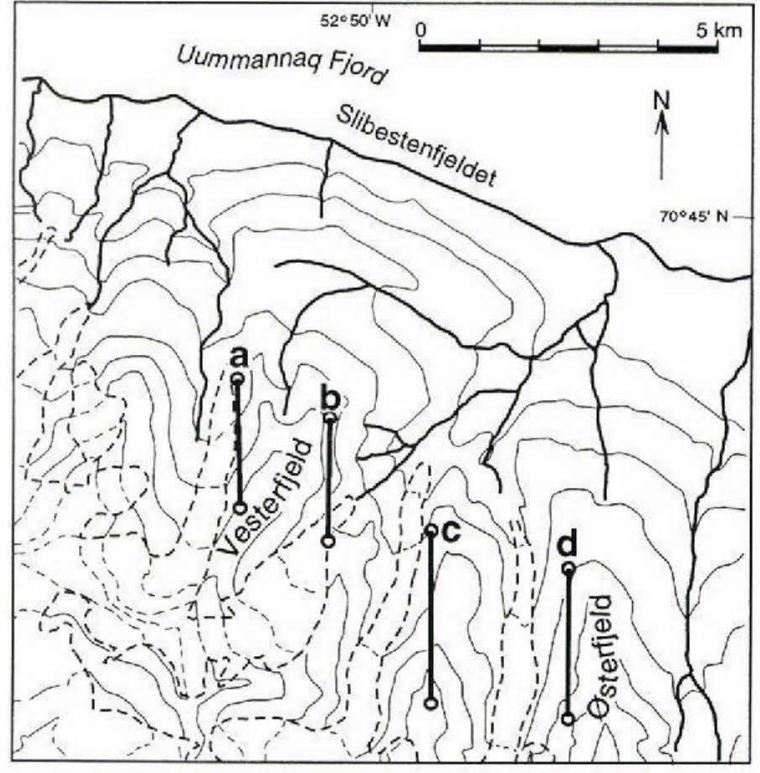

Fig. 10. Four sections through the Tunoqqu Member between Vesterfjeld and Østerfjeld at the north coast of Nuussuaq (index map). The sections were compiled from colour diapositives by multi-model photogrammetry. The projection planes are vertical, northsouth orientated, looking east.

a. West side of Vesterfjeld. Hyaloclastite breccias from the Naujánguit Member (3) are overlain by several units of cross-bedded boulder conglomerates from the Tunoqqu Member $(4,5,6)$ which prograded northwards into the sea. The conglomerates are interbedded with a hyaloclastite horizon (7), and overlain by subaerial lava flows $(10,11)$. The Tunoqqu Member is overlain by hyaloclastite breccias (12) and lavas $(13,14)$ from the Ordlingassoq Member.

b. East side of Vesterfjeld. Precambrian gneiss (1) and Cretaceous to lower Tertiary clastic sediments (2) are overlain by thin discontinuous deposits of hyaloclastite from the Naujánguit Member (3). These are followed by thick deposits of Tunoqqu Member hyaloclastite breccias ( 7$)$ and cross-bedded boulder conglomerates $(5,6)$ which prograded north and north-eastwards into the sea. The clastic rocks are covered by Tunoqqu Member subaerial lava flows $(9,10,11)$. Flow 9 flowed over humid ground, as indicated by its structure with a thick entablature zone. These lavas are covered by hyaloclastite breccias (12) and lava flows $(13,14)$ from the Ordlingassoq Member.

c. West side of Mellemfjeld (Heim, 1910, p. 178). Precambrian gneiss (1) and Cretaceous to lower Tertiary clastic sediments (2) are overlain by more than $200 \mathrm{~m}$ of conglomerates from the Tunoqqu Member. Six conglomerate units are distinguished; they show transport directions towards the east and south-east. An invasive lava (8) is seen in the lower part of the conglomerates. An irregular lava flow (9) with a thick entablature zone has filled a humid erosional? depression in the conglomerates. The Tunoqqu Member ends with subaerial lavas $(10)$ and is overlain by hyaloclastite breccias from the Ordlingassoq Member (12).

d. West side of Østerfjeld. Precambrian gneiss (1) and Cretaceous to lower Tertiary clastic sediments (2) are overlain by foreset-bedded hyaloclastite breccias from the Tunoqqu Member (7). A Tunoqqu Member lava (8) has invaded the lower part of the hyaloclastites. The hyaloclastites are covered by subaerial lavas (11). The Tunoqqu Member is overlain by hyaloclastite breccias (12) and lavas (13) from the Ordlingassoq Member. 


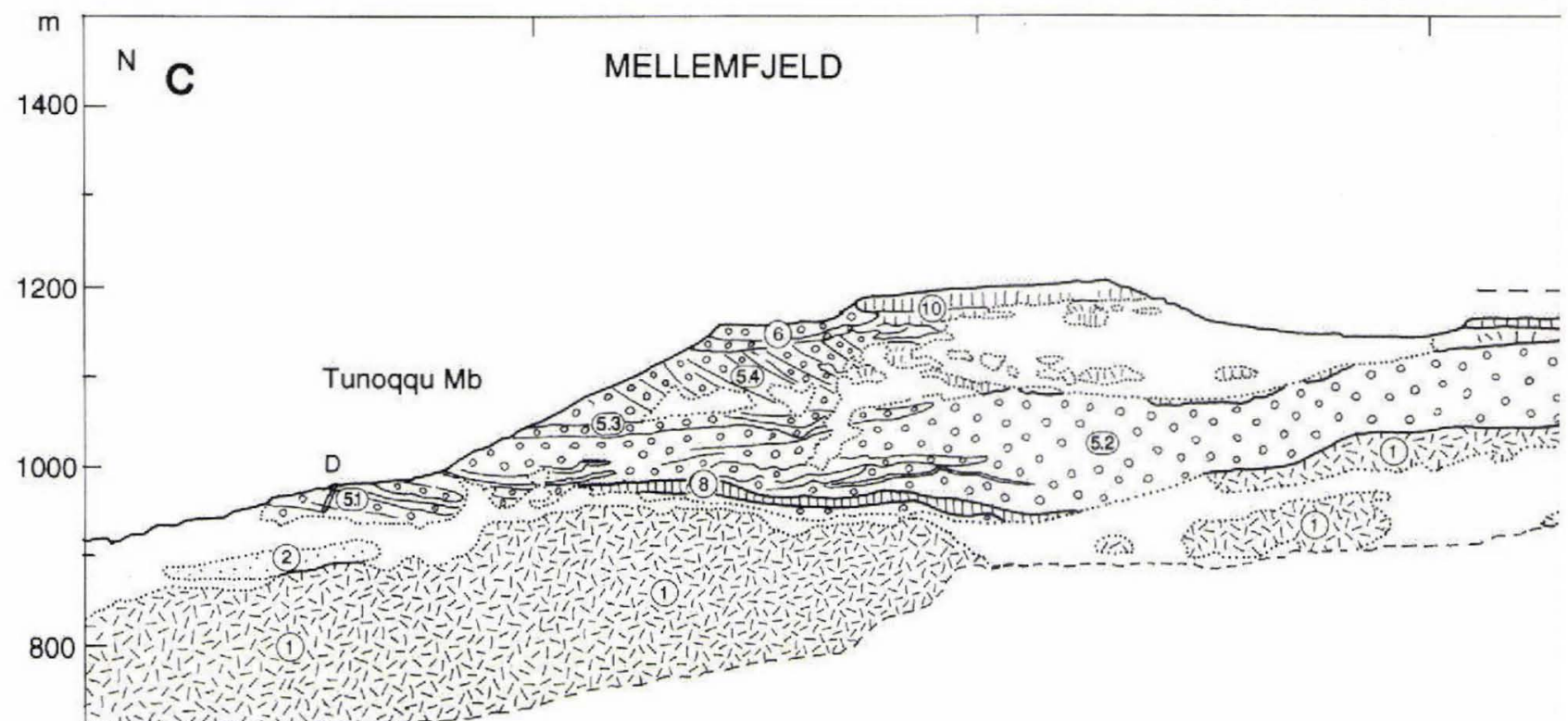

ICE \& TILL
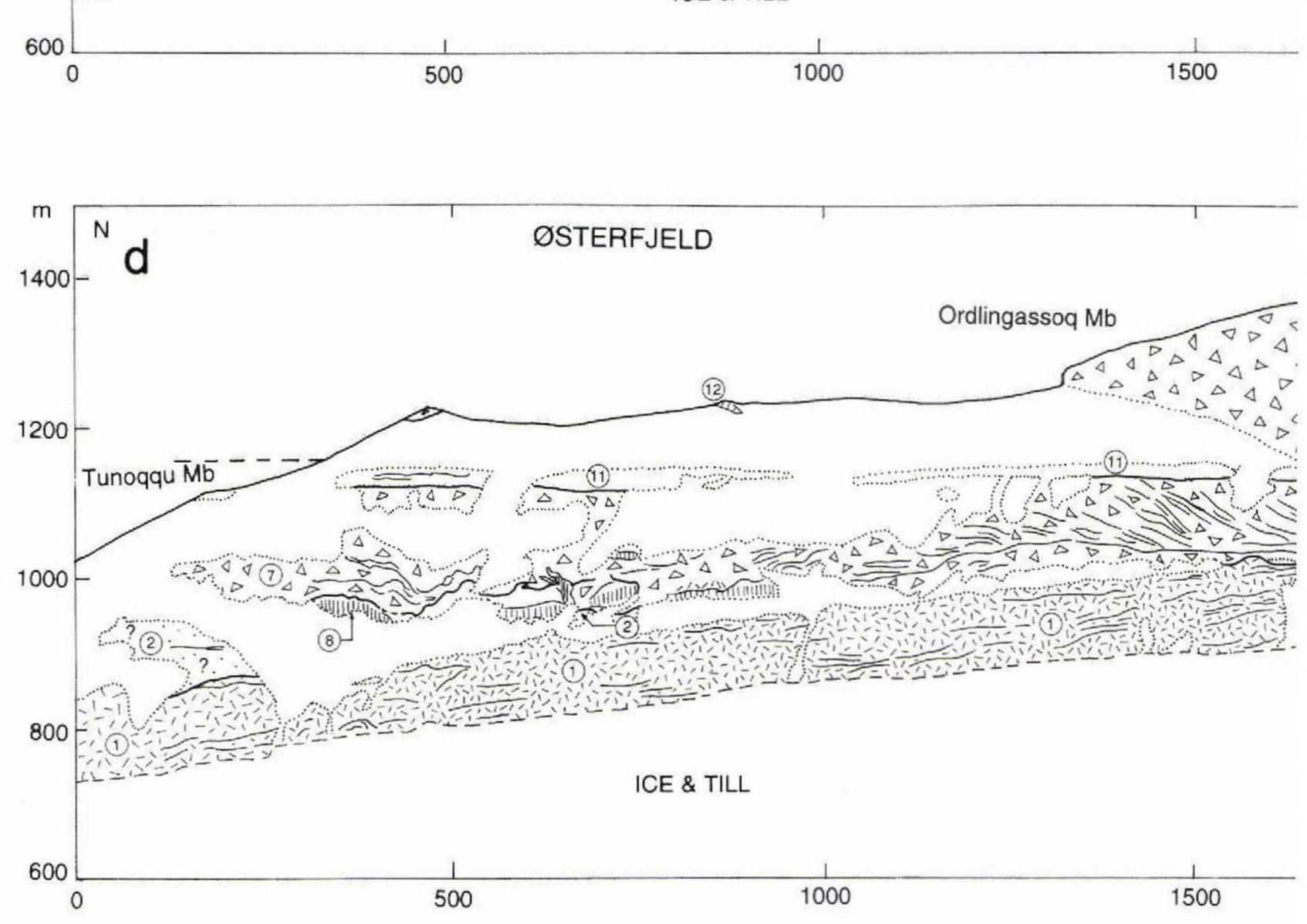

Fig. 10 cont. 


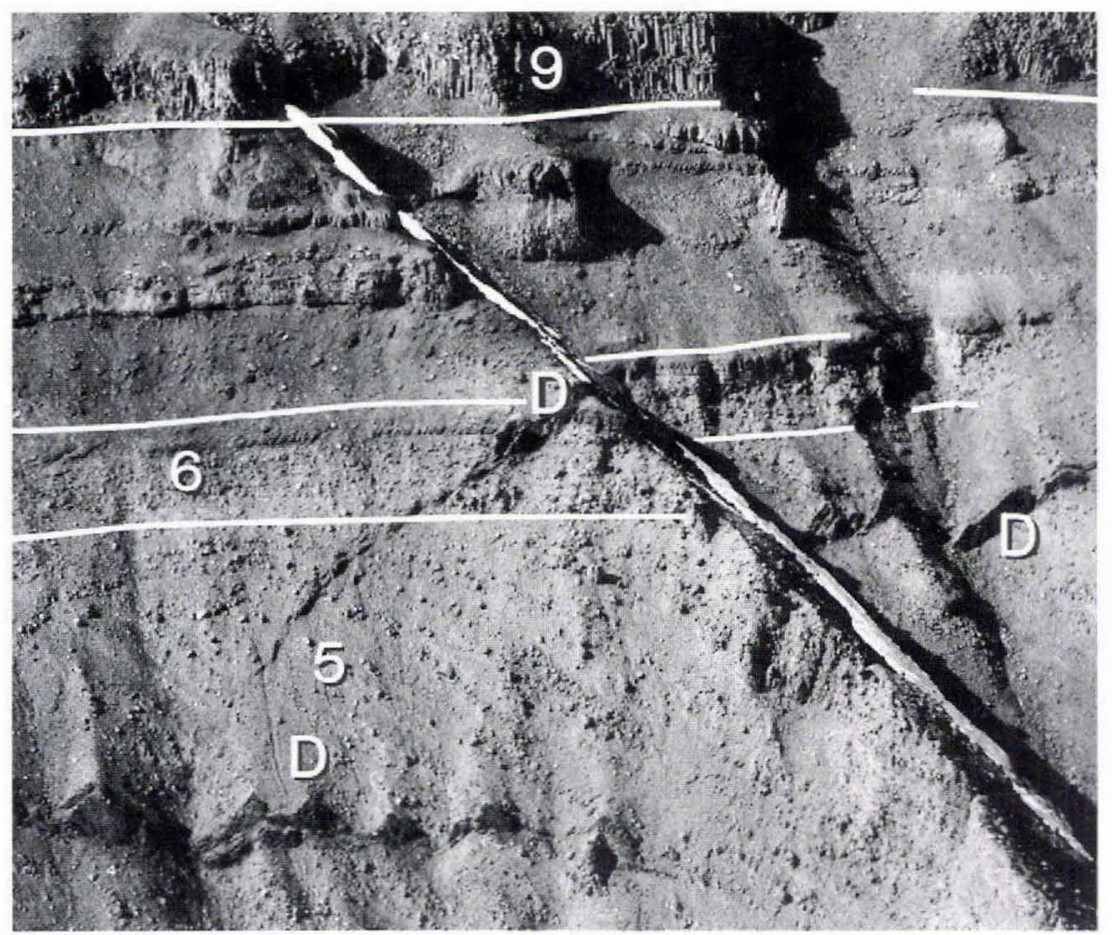

Fig. 11. Tunoqqu Member boulder conglomerates. Top: Thick, crossbedded conglomerates (5) overlain by horizontally bedded conglomerates (6), overlain by subaerial lavas. Basaltic dykes (D) cut the conglomerates. East side of Vesterfjeld; numbers are the same as in Fig. 10. Bottom: Conglomerate with large rounded blocks of vesicular lava and numerous small rounded pebbles of hyaloclastite. The matrix is hyaloclastite sand.

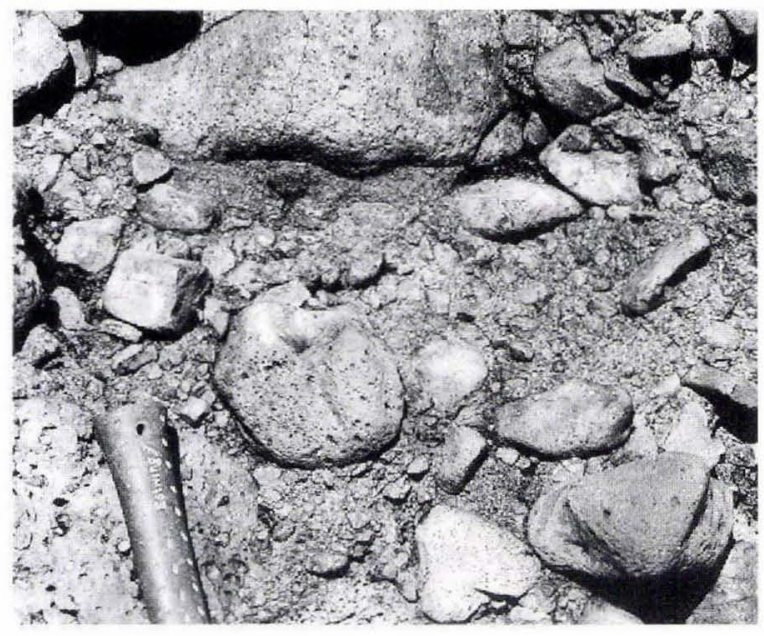

of light brown Tunoqqu Member hyaloclastites or conglomerates are exposed, banked up against a sloping gneiss surface which rose $200 \mathrm{~m}$ above them (Fig. 9). The Tunoqqu Member rocks are covered by $325 \mathrm{~m}$ of Ordlingassoq Member picrite hyaloclastites which are also banked up against the gneiss. The locality marks the point where the advancing Tunoqqu Member volcanic rocks reached the gneiss promontory. However, the thick Ordlingassoq Member hyaloclastites show that a permanent land bridge between the lava plateau and the gneiss was not established.

\section{North coast of Nuussuaq from Vesterfjeld to Østerfjeld}

In this area, the Tunoqqu Member possesses a complicated geological structure and large lithological variations. A prominent feature is the occurrence of thick, foreset-bedded boulder conglomerates. The rocks have been studied in four parallel $\mathrm{N}-\mathrm{S}$ orientated valley sections $2.5-3.5 \mathrm{~km}$ in length, and covering an $\mathrm{E}-\mathrm{W}$ distance of $7 \mathrm{~km}$ (Fig. 10).

The substrate for the Tunoqqu Member varies from section a to section d in Fig. 11. In section a, the substrate consists of foreset-bedded picritic hyaloclastite breccias from the Naujánguit Member. These are more than $100 \mathrm{~m}$ thick and were filled in from the south-west. Thin interlayered mudstones with a few Tertiary dinoflagellate cysts (S. Piasecki, personal communication, 1994) show that the hyaloclastites were deposited in a marine environment. On the eroded top of these hyaloclastites is deposited an up to $50 \mathrm{~m}$ thick very coarse, cross-bedded grey conglomerate with lava boulders up to $2.5 \mathrm{~m}$ in size consisting of olivine basalt and subordinate aphyric basalt and gneiss blocks. In section b, only a very thin layer of picritic hyaloclastite separates sediments and Tunoqqu Member rocks. In sections $\mathrm{c}$ and $\mathrm{d}$ the northsloping surface of the gneiss promontory is well exposed and rises high to the south. Poorly exposed Cretaceous sediments cover the northern tip of the gneiss in section c. In section d, coarse sandstone and mudstone deposited on 


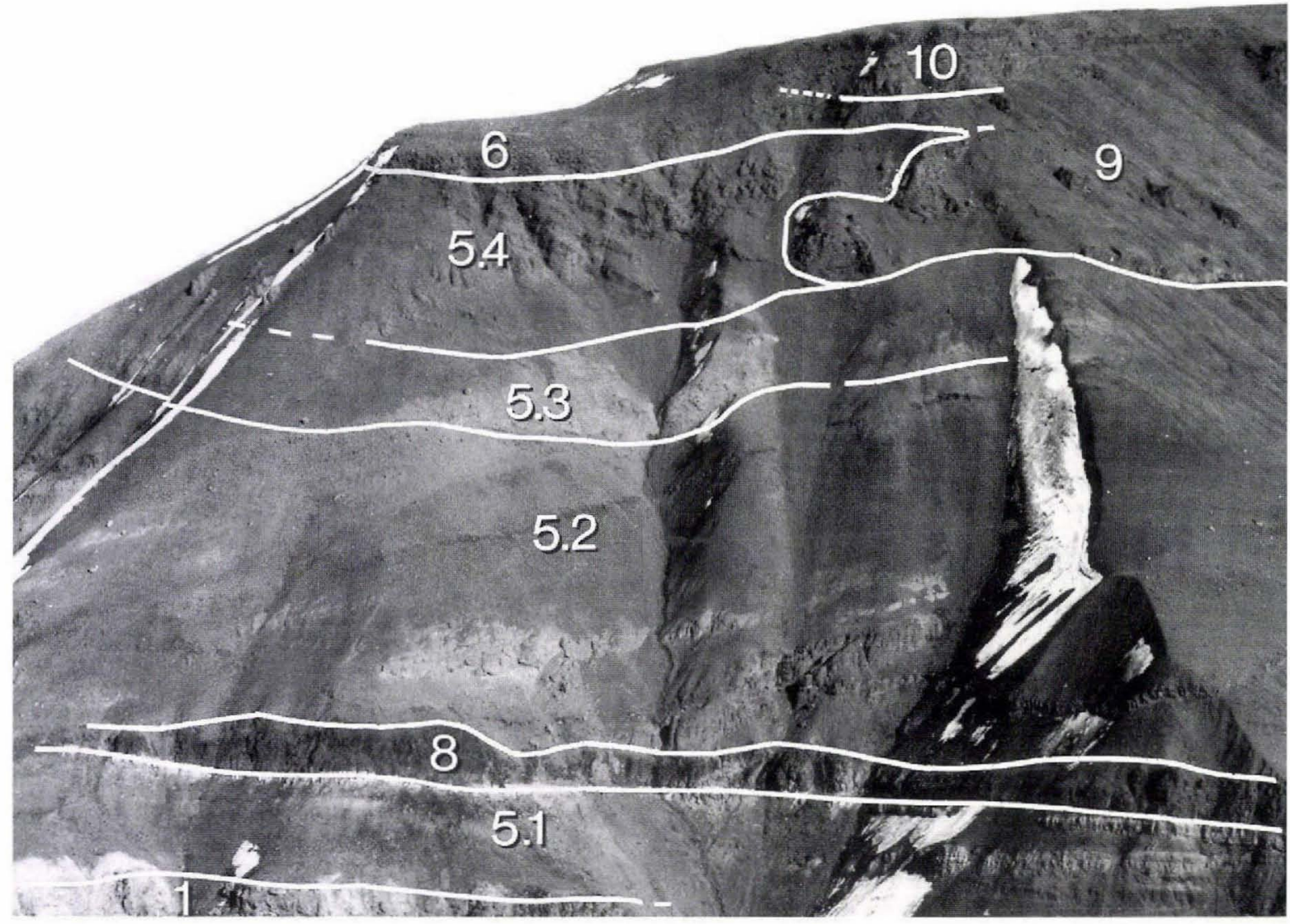

Fig. 12. The west side of Mellemfjeld (Fig. 10 c). Numbers are the same as in Fig. 10. Five different conglomerate units (5.1 to 5.4 and 6) from the Tunoqqu Member overlie Precambrian gneiss (1). An invasive lava (8), a strongly columnar-jointed lava indicating a humid environment (9), and normal subaerial lavas (10) also belong to the Tunoqqu Member. Note that the deposition of the strongly cross-bedded conglomerate unit 5.4 was contemporaneous with the emplacement of the lava 9.

the weathered gneiss surface are exposed locally. Over most of sections $\mathrm{c}$ and $\mathrm{d}$, Tunoqqu Member rocks rest directly on the gneiss.

Sections $a$ and $b$ (Vesterfjeld west and east). In section $b$, the Tunoqqu Member starts with orange-brown foreset-bedded hyaloclastites which entered from the SW into a $130-150 \mathrm{~m}$ deep water-filled basin where they prograded more than $1.3 \mathrm{~km}$ towards the NE. The lavas probably entered the basin near to this locality. The preTunoqqu Member units in section a and the hyaloclastite unit in section $b$ are eroded on the top and covered by a $20 \mathrm{~m}$ thick conglomerate bed which continued the progressive infilling of the basin. The conglomerate forms a cross-bedded orange-brown deposit which is almost indistinguishable from hyaloclastite when seen from a distance. It consists of up to $0.7 \mathrm{~m}$ large lava blocks of silicic low-Mg basalt with subordinate olivine-phyric basalt and gneiss blocks (Fig. 11). In addition, rounded pillow fragments with glassy margins are found, and the conglomerate matrix is rich in glass gravel derived from reworked Tunoqqu Member hyaloclastite.

The conglomerate unit is covered by pahoehoe lavas which pass into shallow hyaloclastite facies with transport directions from the south, seen in the northern part of section b. In section a, a single $10-30 \mathrm{~m}$ thick hyaloclastite bed shows infill from the north and north-west.

This unit is covered by an up to $15 \mathrm{~m}$ thick conglomerate bed (sections $a$ and $b$ ) showing transport directions from the south. It contains blocks of Tunoqqu Member lavas and hyaloclastites, and subordinate gneiss blocks.

In sections $\mathrm{a}$ and $\mathrm{b}$ five subaerial Tunoqqu Member lava flows follow next, of which the lowest has a very regular and prominent colonnade indicating that it flowed over humid ground. In section b, this flow is seen to invade and disrupt the underlying conglomerate.

Between sections $\mathrm{b}$ and $\mathrm{c}$ a marked change in lithology 
takes place and sections $\mathrm{c}$ and $\mathrm{d}$ are described separately.

In section c (Mellemfjeld) there is a remarkable development of conglomerates. These are up to $250 \mathrm{~m}$ thick and consist of at least five separate units described below.

Conglomerate 1 (Fig. 10, section c, unit 5.1) is up to $30 \mathrm{~m}$ thick and consists of a number of distinct, flat-lying beds with blocks of Tunoqqu Member lavas, reworked hyaloclastite, and subordinate gneiss. It also contains scattered fragments of petrified wood.

An intrusive sheet of basalt (Fig. 10, section c, unit 8) separates conglomerates 1 and 2. Because of its distinctive chemical composition the sheet is correlated with subaerial lava 3 on Vesterfjeld, and it is probably an invasive tongue of that lava.

Conglomerate 2 (Fig. 10, section c, unit 5.2) is up to $120 \mathrm{~m}$ thick and may be a continuation of conglomerate 1 . It contains beds of glassy hyaloclastite gravel. A shallow trough is eroded into its top.

Conglomerate 3 (Fig. 10, section c, unit 5.3) is a distinctive, $5-10 \mathrm{~m}$ thick light-coloured bed.

Conglomerate 4 (Fig. 10, section c, unit 5.4) is an up to $70 \mathrm{~m}$ thick, brown, regularly cross-bedded conglomerate or hyaloclastite filled in from the north or north-west. It has not been visited in the field. To the south, the foresets interfinger steeply with a number of columnar-jointed, subaqueous or at least humid-facies-type lava tongues which have also filled the shallow trough in the top of conglomerate 2 . These lavas can be correlated with subaerial lavas 4 and 5 on Vesterfjeld, indicating that at least some of the conglomerates in section $c$ are younger than any of those in sections $a$ and $b$.

Conglomerate 5 (Fig. 10, section c, unit 6) is up to $25 \mathrm{~m}$ thick and consists of a number of very coarse beds with well-rounded basalt boulders up to $1 \mathrm{~m}$ in size. To the south, it interfingers with subaerial lava flows (unit 10 ), and it must have been deposited in a shallow river bed with torrential water flow. This river existed at least during the time interval covered by the eruption of two successive lavas, probably the last ones in the Tunoqqu Member.

A photo of the Mellemfjeld section is shown in Fig. 12.

In section $d(\emptyset$ sterfjeld) the lithology is much simpler and no conglomerates are present. The Tunoqqu Member is banked up against the gneiss and varies in thickness from 0 to more than $250 \mathrm{~m}$. Three volcanic units are present.

The lowest unit (Fig. 10, section d, unit 8) is up to $120 \mathrm{~m}$ thick and composed of strongly columnarjointed, irregular basalt overlain by pillow lava and hyaloclastite (S. Munck \& A. Noe-Nygaard, unpublished field notes), probably subaqueous lava tongues. These are veined and intruded by irregular, approximately N-S trending dykelike bodies.
The middle unit (no 7) is an up to $100 \mathrm{~m}$ thick, regularly foreset-bedded, orange-brown hyaloclastite deposited from the north.

The upper unit (no 11) is up to $25 \mathrm{~m}$ thick and composed of brown subaerial lavas.

Ordlingassoq Member. In the western area (sections a and b) a few subaerial picrite lavas overlie the Tunoqqu Member, followed by subaqueous lavas and hyaloclastite. In the eastern area (sections $\mathrm{c}$ and d) Ordlingassoq Member hyaloclastites directly overlie the Tunoqqu Member, and in section $d$ they show infilling from the north.

\section{Summary of events in the north coast area (Fig. 13)}

1. At the start of Tunoqqu Member time the western shoreline was marked by an earlier hyaloclastite deposited towards the NE. Seawards of this, a conglomerate with metre-sized boulders of olivine basalt and gneiss was deposited towards the north and NE, indicating the start of local erosion (Fig. 11, section a).

2. A Tunoqqu Member foreset-bedded hyaloclastite advanced farther towards the NE (Fig. 10, sections a and $b$ ).

3. Over a several kilometres broad area, blocks of Tunoqqu Member lavas and hyaloclastites, and gneiss, were transported towards the NE and deposited in a 150 $\mathrm{m}$ thick conglomerate fan (Fig. 10, sections a and b).

4. Further advance of Tunoqqu Member subaerial lavas and equivalent hyaloclastites (Fig. 10, sections a and $b$ ).

5. Further erosion and deposition of conglomerates (Fig. 10, sections a-c). High-energy torrential flows started to transport the conglomerates towards the east (section c).

6. The volcanic front advanced from the west; sections $a-b$ were then on dry land. The water flow was increasingly constrained between the gneiss promontory and the lava plain and deflected towards the east, still depositing conglomerates, the youngest from the north. Concomitantly, lavas repeatedly flowed into the river bed and threatened to block it completely (Fig. 10, section c).

7. The volcanic front engulfed the gneiss promontory, swung eastwards, and deposited hyaloclastites towards the SE and south (Fig. 10, section d). Finally, the river ceased to flow and the emergent hyaloclastites and conglomerates were covered by subaerial Tunoqqu Member lava flows which formed a horizontal plain around the gneiss 'promontory' which still rose to more than $700 \mathrm{~m}$ above the lavas.

8. In Ordlingassoq Member time, the plain was again inundated by a several hundred metres deep water-filled basin. 


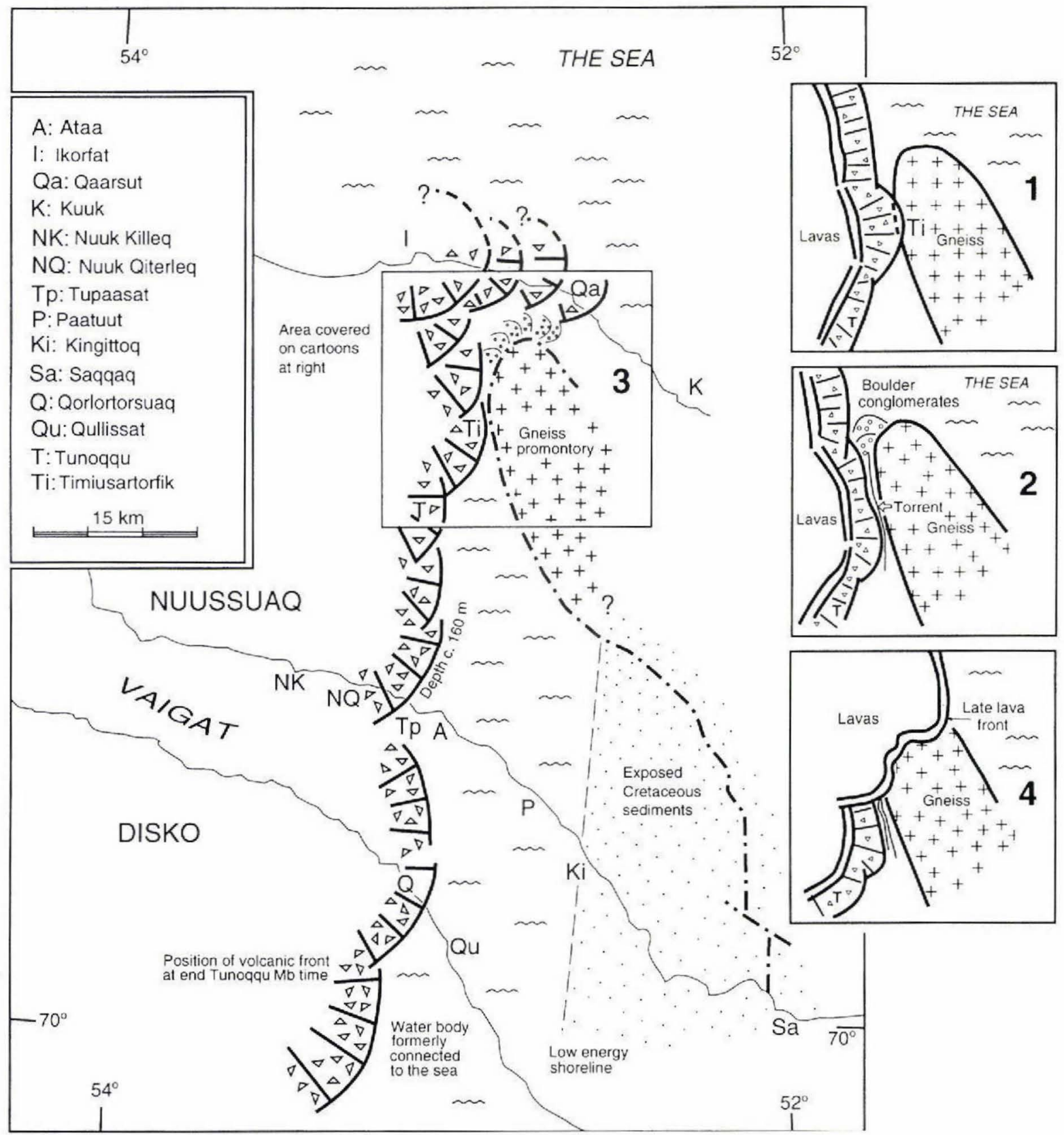

Fig. 13. Sketch of the palaeogeography of central Nuussuaq and north-eastern Disko at Tunoqqu Member time. A water body with a depth of $c .160 \mathrm{~m}$ was confined between a high gneiss promontory in the north-east, a low-energy clastic shoreline in the east, and the advancing volcanic front in the west, leaving only a narrow connection to the sea in the north. Three stages in the development are illustrated on separate maps. 1. Progradation of Tunoqqu Member hyaloclastites towards the east. At a single locality (Timiusartorfik) the hyaloclastite onlaps the gneiss surface. 2. Fluvial erosion occurs between the easily erodible Tunoqqu Member volcanic rocks and the gneiss promontory. A boulder conglomerate is deposited in front of the torrent. 3. Continued volcanic activity produces additional hyaloclastites and lavas in the north, which force the conglomerates eastwards. 4. Finally, both volcanics and conglomerates are covered by subaerial lava flows onlapping the gneiss. 


\section{Interpretations and conclusions}

\section{Fractionation and contamination at the end of a magmatic cycle}

The volcanic rocks of the Tunoqqu Member on Nuussuaq and the contemporary Kûgánguaq Member on Disko show an unusually large compositional diversity which can not all be explained by crystal fractionation processes. Many of the compositional groups were formed by various degrees of crustal contamination of various parent magmas which ranged in composition from picrite with around $18 \% \mathrm{MgO}$ to evolved feldspar-phyric basalts with around $7 \% \mathrm{MgO}$. The rocks of the Tunoqqu and Kûgánguaq Members are the most widespread and voluminous products of the crustal contamination that took place during the deposition of the Vaigat Formation.

Contamination of the magmas took place in a number of separate magma chambers situated high in the crust, probably in the sediments of the West Greenland Basin. Pedersen (1985b) showed that the dominant contaminant of the Kûgánguaq Member rocks is most likely a sulphurbearing sandstone; the contaminants for the rocks of the Tunoqqu Member are poorly constrained.

Contamination usually induces crystallisation and decrease of $\mathrm{MgO}$ in the contaminated magmas. However, some of the low-MgO basalts of the Tunoqqu Member are not noticeably contaminated and must mainly have formed by normal fractional crystallisation of more $\mathrm{Mg}$ rich, probably picritic parent magmas. This evolution must also have taken place in magma chambers which could have been more deep-seated than the chambers where the contamination took place.

Dwindling magma supply rates at the end of a magmatic cycle may explain the preponderance of evolved and contaminated basalts in the Tunoqqu and Kûgánguaq Members. Dwindling magma supply rates would lead to longer residence times in magma chambers and formation of evolved basalts. Likewise, the likelihood that the magmas would stagnate and react with their surroundings at higher levels on their way to the surface would be increased.

The occurrence of slightly enriched lavas at the top of the Tunoqqu Member may herald the start of the third volcanic cycle in the region, which produced picrites that were slightly enriched relative to those of the preceding cycle.

\section{Tectonic control}

Detailed structural analysis by photogrammetry in wellexposed areas has shown that there is a connection between the position of the eruption centres, the config- uration of fault blocks, and the location of zones with subtle synvolcanic movements.

The Kûgánguaq centre is located along an old palaeoescarpment related to the Disko Gneiss Ridge (Fig. 1). The Qunnilik centre is situated due north of this and may be related to a northern prolongation of this gneiss ridge. The Tupaasat centre formed within an area which at that time was affected by repeated small vertical movements. Finally, the Agatdal centre is situated somewhere along the south-western margin of the Ikorfat fault system which was affected by semi-continuous, probably tensionrelated, sagging in Naujánguit Member time.

The more regionally dispersed and less contaminated lavas could have been erupted from fissures outside the centres. Dykes with fairly similar chemistry occur at various places, but they are not sufficiently characteristic to be related unequivocally to the Tunoqqu Member because the much younger Maligât Formation contains very similar basalts.

In conclusion, all the known eruption sites were situated in tectonically active zones, and it is probable that magmas were channelled towards the surface and developed magma chambers along pre-existing, deep faults.

The ultimate cause for the magmatic stagnation at the end of the Naujánguit Member cycle is not known. Based on the observations above, it may be speculated that the stagnation was tectonically controlled, e.g. caused by a slight shift in the direction and magnitude of the tectonic forces driving the plates in the Baffin Bay region.

\section{Conglomerates and basin development}

The spectacular Tunoqqu Member conglomerates at the north coast of Nuussuaq were deposited by torrents along the gneiss promontory. The cause of the development of the conglomerates could be either 1. a relative sea-level rise, 2. a relative sea-level fall, 3 . local tectonic movements, or 4. non-tectonic damming of a large water body.

1. A relative sea-level rise may be caused by the loading effect of the heavy volcanic rocks. It would lead to formation of coastal cliffs of eroded lavas and deposition of local conglomerates at the foot of the cliffs, as described for the Tunoqqu type locality. But transport of metre-sized gneiss blocks over several kilometres would not be possible, and a relative sea-level rise cannot explain the north coast conglomerates.

2. A relative sea-level fall leading to rejuvenation of water courses may lead to deposition of conglomerates. It should also be expressed as falling palaeoshore levels. The palaeoshore levels are recorded very precisely in the volcanic facies, where falling sea-level should give rise to a lowering of the top of the hyaloclastite level. Such a feature has not been observed. 
3. Localised syn-volcanic movements may also lead to rejuvenation of water courses. Syn-volcanic uplift has been observed along the south coast of Nuussuaq (Pedersen et al., 1993), and sagging has been observed along the south-western margin of the Ikorfat fault system. None of these movements would be likely to trigger high-energy flows across the Ikorfat fault system from the Agatdal region towards the north-east.

4. From the discussion above we conclude that relative sea-level changes cannot explain the observations. We therefore interpret the conglomerates as caused by a simple damming effect. The eastward-prograding volcanic rocks gradually obliterated the marine embayment in central Nuussuaq, but north-flowing water courses in the eastern Disko Bugt region would still exist. Because of the damming the water table rose, and the increased gradient between the enclosed basin and the sea to the north generated an outlet torrent between the volcanic front and the gneiss promontory.

Acknowledgements. The field work was carried out during GGU expeditions led by F. Kalsbeek and F. G. Christiansen. Field support was also provided by the Arctic Station in Godhavn. AKP and GKP were supported by the Danish Natural Science Research Council (grant no. 11-8949-1).

\section{References}

Clarke, D. B. \& Pedersen, A. K. 1976: Tertiary volcanic province of West Greenland. In Escher, A. \& Watt, W. S. (ed.) Geology of Greenland, 364-385. Copenhagen: Geol. Surv. Greenland.

Croxton, C. A. 1978: Report on field work undertaken between $69^{\circ}$ and $72^{\circ} \mathrm{N}$, central West Greenland in 1975 with preliminary palynological results. Open File Report Grønlands geol. Unders. 78-1, 88 pp.

Dam, G. \& Sønderholm, M. (in press). Sedimentological evolution of a fault-controlled Early Paleocene incised valley system, Nuussuaq Basin, West Greenland. In Shanley, K. W. \& McCabe, P. J. (ed.) Relative role of eustasy, climate, and tectonism in continental rocks. Spec. Publ. Soc. Econ. Palaeont. Miner.

Dueholm, K. S. \& Pedersen, A. K. (ed.) 1992: Geological analysis and mapping using multi-model photogrammetry. Rapp. Grønlands geol. Unders. 156, $72 \mathrm{pp}$.

Garde, A. A. \& Steenfelt, A. (in press): Precambrian geology of Nuussuaq and the area north-east of Disko Bugt, West Greenland. Rapp. Gronlands geol. Unders.

Hald, N. 1977: Lithostratigraphy of the Maligât and Hareøen Formations, West Greenland basalt group, on Hareøen and western Nûgssuaq. Rapp. Grønlands geol. Unders. 79, 9-16.

Hald, N. \& Pedersen, A. K. 1975: Lithostratigraphy of the early Tertiary volcanic rocks of central West Greenland. Rapp. Gronlands geol. Unders. 69, 17-24.

Heim, A. 1910: Über die Petrographie und Geologie der Umgebungen von Karsuarsuk, Nordseite der Halbinsel Nugsuak, W. Grönland. Meddr Grønland 47, 173-228.

Henderson, G. 1973: The geological setting of the West Green- land basin in the Baffin Bay region. Pap. Geol. Surv. Canada 71-23, 521-544.

Henderson, G. \& Pulvertaft, T. C. R. 1987: Geological map of Greenland 1:100 000. Descriptive text. Mârmorilik 71V 2 Syd, Nûgâtsiaq 71 V 2 Nord, Pangnertôq 72 V 2 Syd. Lithostratigraphy and structure of a Lower Proterozoic dome and nappe complex. Copenhagen: Grønlands Geologiske Undersøgelse, 72 pp.

Henderson, G., Schiener, E. J., Risum, J. B., Croxton, C. A. \& Andersen, B. B. 1981: The West Greenland Basin. In Kerr, J. W. (ed) Geology of the North Atlantic Borderlands. Mem. Can. Soc. Petrol. Geol. 7, 399-428.

Hjortkjær, B. F. 1991: Palynologisk unders $\emptyset$ gelse af tertiære skifre fra Disko og Nûgssuaq, Vestgrønland. Unpublished thesis, University of Copenhagen, 94 pp. \& plates.

Koch, B. E. 1959: Contribution to the stratigraphy of the nonmarine Tertiary deposits on the south coast of the Nûgssuaq Peninsula, northwest Greenland. Bull. Gronlands geol. Unders. 22, 100 pp. (Also Meddr Grønland 162, 1).

Koppelhus, E. B. \& Pedersen, G. K. 1993: A palynological and sedimentological study of Cretaceous floodplain deposits of the Atane Formation at Skansen and Illunnguaq, Disko, West Greenland. Cretaceous Res. 14, 707-734.

Larsen, L. M. \& Pedersen, A. K. 1988: Investigations of Tertiary volcanic rocks along the south coast of Nûgssuaq and in eastern Disko, 1987. Rapp. Gronlands geol. Unders. 140, 28-32.

Larsen, L. M. \& Pedersen, A. K. 1992: Volcanic marker horizons in the upper part of the Maligât Formation on eastern Disko and Nuussuaq, Tertiary of West Greenland: syn- to post-volcanic basin movements. Rapp. Grønlands geol. Unders. 155, 85-93.

Larsen, L. M., Pedersen, A. K., Pedersen, B. K. \& Piasecki, S. 1992: Timing and duration of Early Tertiary volcanism in the North Atlantic: new evidence from West Greenland. In Storey, B. C. Alabaster, T. \& Pankhurst, R. J. (ed.) Magmatism and the causes of continental break-up. Spec. Publ. Geol. Soc., London 68, 321-333.

Nøhr-Hansen, H. 1994: Dinoflagellate cyst biostratigraphy of the Upper Cretaceous black mudstones in central Nuussuaq, West Greenland. Open File Ser. Grønlands geol. Unders. 94-12, $26 \mathrm{pp}$.

Nøhr-Hansen, H. (in press): Upper Cretaceous dinoflagellate cyst stratigraphy, onshore West Greenland. Bull. Grønlands geol. Unders. 170.

Pedersen, A. K. 1977: Dyke intrusions along the south coast of Disko. Rapp. Gronlands geol. Unders. 81, 57-67.

Pedersen, A. K. 1979: Basaltic glass with high-temperature equilibrated immiscible sulphide bodies with native iron from Disko, central West Greenland. Contrib. Miner. Petrol. 96, 397-407.

Pedersen, A. K. 1985a: Lithostratigraphy of the Tertiary Vaigat Formation on Disko, central West Greenland. Rapp. Grønlands geol. Unders. 124, $30 \mathrm{pp}$.

Pedersen, A. K. 1985b: Reaction between picrite magma and continental crust: early Tertiary silicic basalts and magnesian andesites from Disko, West Greenland. Bull. Grønlands geol. Unders. 152, $126 \mathrm{pp}$. 
Pedersen, A. K. \& Dueholm, K. S. 1992: New methods for the geological analysis of Tertiary volcanic formations on Nuussuaq and Disko, central West Greenland, using multi-model photogrammetry. Rapp. Grønlands geol. Unders. 156, 19-34.

Pedersen, A. K., Larsen, L. M. \& Dueholm, K. S. 1993: Geological section along the south coast of Nuussuaq, central West Greenland. 1:20 000 coloured geological sheet. Copenhagen: Geol. Surv. Greenland.

Pedersen, G. K. 1989: A fluvial-dominated lacustrine delta in a volcanic province, W Greenland. In Whateley, M. K. G. \& Pickering, K. T. (ed.) Deltas: sites and traps for fossil fuels. Spec. Publ. Geol. Soc., London 41, 139-146.

Pedersen, G. K. \& Pulvertaft, T. C. R. 1992: The nonmarine Cretaceous of The West Greenland Basin, onshore West Greenland. Cretaceous Res. 13, 263-272.

Piasecki, S., Larsen, L. M., Pedersen, A. K. \& Pedersen, G. K. 1992: Palynostratigraphy of the Lower Tertiary volcanics and marine clastic sediments in the southern part of the West Greenland Basin: implications for the timing and duration of the volcanism. Rapp. Grønlands geol. Unders. 154, 13-31.

Pulvertaft, T. C. R. 1979; Lower Cretaceous fluvial-deltaic sediments at Kâk, Nûgssuaq, West Greenland, Bull. Geol. Soc. Denmark 28, 57-72.

Pulvertaft, T. C. R. 1989: Reinvestigation of the Cretaceous boundary fault in Sarqaqdalen, Nûgssuaq, central West Greenland. Rapp. Gronlands geol. Unders. 145, 28-32.

Rosenkrantz, A. 1970: Marine Upper Cretaceous and lowermost Tertiary deposits in West Greenland. Bull. Geol. Soc, Denmark 19, 406-453.

Rosenkrantz, A. \& Pulvertaft; T. C. R. 1969: Cretaceous-Tertiary stratigraphy and tectonics in northern West Greenland. Mem. Amer. Ass. Petrol. Geol. 12, 883-898. 